University of Louisville

ThinkIR: The University of Louisville's Institutional Repository

Electronic Theses and Dissertations

1937

\title{
The effect of drugs on experimental renal hypertension in the dog.
}

J. J. Prusmack

University of Louisville

Follow this and additional works at: https://ir.library.louisville.edu/etd

Part of the Medicinal Chemistry and Pharmaceutics Commons, and the Physiology Commons

\section{Recommended Citation}

Prusmack, J. J., "The effect of drugs on experimental renal hypertension in the dog." (1937). Electronic Theses and Dissertations. Paper 1852.

https://doi.org/10.18297/etd/1852

This Master's Thesis is brought to you for free and open access by ThinkIR: The University of Louisville's Institutional Repository. It has been accepted for inclusion in Electronic Theses and Dissertations by an authorized administrator of ThinkIR: The University of Louisville's Institutional Repository. This title appears here courtesy of the author, who has retained all other copyrights. For more information, please contact thinkir@louisville.edu. 
ODIVERSITY OP IOOISVIITS

THE EFTECT OF DRUGS ON FTPERTIGMILI REITAL

HYPERTENSION IN THE DOG

\author{
$\triangle$ Diseortation \\ Submitted to the Paoulty \\ Of the Graduate Sohool of the University of Louisvillo \\ In Partial Fulfillment of the \\ Boquirement. for the Degree \\ or Yaster of solenee
}

Department of Physiology and Pharmaoology

By

J. J. Pruameck

1937

42544 


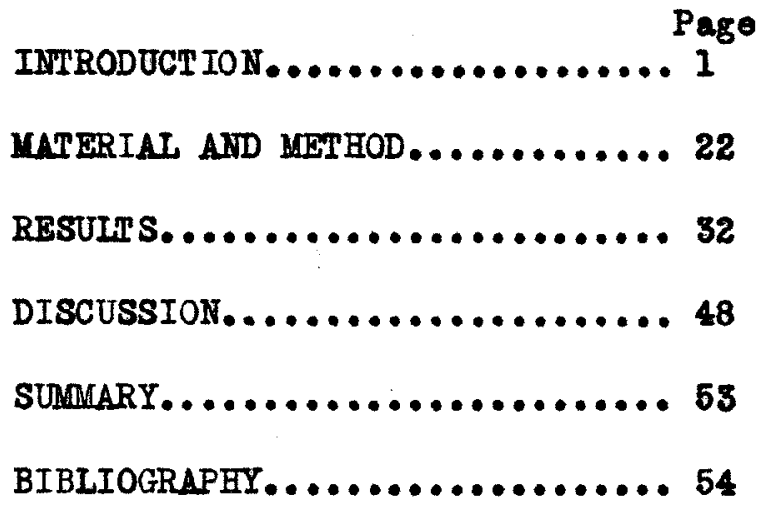




\section{ACKNOWLEDGMENT}

I desire to express my deepest gratitude and appreciation to Professor G. B. Nakerlin for the inspiration and guidance ho has giren me. I also Wh to thank Dr. M. M. Woiss for his aid and interest in this invostigation, and Dr. Maloolm Thompson $f$ or his assistance with the surgery on the $\operatorname{dog} 8$ 
IITRODUCTION

Iffetines of study hare been deroted to eluoidation of the Intricate problems of cardiovasoular physiology and pathology. and elinical applications hare kept pace. However, efforts directed to the deternination of the causes of so-oalled degenerative ciroulatory diseases and to the discovery of effective treatment hare met failure at almost every turn. Of late years, Indeed, these conditions, whother by reason of better diagnosia, greater population of suseoptible age groups or other ohanges, appear to be lnoreasing in frequenoy. $I$ review, however of the clinical significance of changes in arterial pressure, 1s one of colossal magnitude fran the point of view alone of the published literature referable to it, and it would seem a truise that the less a subjeot is understood tho more 10 witten about it.

The etiology of olinioal hypertension is still largely untnom(1). Vory little has been added to the knowledge of the subject sine Janeway's masterly roviows in 1904 (2) and 1913(3). Tho atudy of arterial hyportension really dates back to Bright(4) who was the first to observe that profound imrolvement of the oardio-rascular systen is associatod with ronal disesse. In his first memoir, the great olinioian noted the increased resistanoe whioh the arteries of the diseased kidney offer to injeotion and a little later ho also desoribed the occurence of oardiac hypertrophy in the sane oondition. Shortly after Bright's oomunioation, Toymbeo(5) mowed that in the oontracted kidney the mall arteries are thiokened and narrowed, thereby acoounting for the difficulty that Bright had encountered in injeoting ouch organs. In 1858, Johnson(6) found that the thickening of the mall arteries in Bright's disease is not confined to the kidney, but it is also present in the arterioles of other organs. 
Fract neasurenents of the hydrostatio pressure under wioh the blood exiats in the large arteries and reins were first publishod by the Rev. Dr. Stephen Halos(7) an English olorgynan, in his famous book ortitled "Statioal Essays, containing Haemostaticks," 1735. This observor measured the static pressure of the blood in the arteries and reins by the simplest direot method possible. After tying the femoral artery in a horse ho oconooted it to a glass tube 9 feot tn length. On opening the ressel the blood nounted in the tube to a height of 8 feet 3 inches, showing that normaly, in the elosed artery, the blood is wader a tension suffielent to oupport a colvom of blood of this height.

sinoe Hales' work, the ohlef improvement in method which have marked and oaused the derelopment of this part of the subjeot have been the epplioation of the meroury manameter by Polseville(8), the invention of the reoordins manometer and kynographion by Ludifg(9), and the later numerous improvements by many physiologists. While attempts at instrumental, 1ndirect measurement of the arterial pressure in man date hack to Vierordt(10), and extensire ostimations were made by ron Basoh(11). Potain(12) and othere, wide-spread olinical measurement of blood pressure only followed the introduotion of the pnewatio ouff for ocmpression of the artery by Rira-Rooc1(13) in 1896.

Considerable differenoes are found in the normal arterial blood prossure of hoalthy indiriduals, the arterial tension not being hold at nearly so fixed a velue as is, for example, the hydrogen-ion concentration of the blood. scue of the faotors assoolated with rariations in blood pressure are bom, including ago, woight, sex, nutritional state, and olimatio onviroment, as woll as inborn, individual oonstitutionsl peouliarities. The range in- Inded in the normal rariation of blood pressure is, howrever, not as broad as was formerly thought, though one is comotimes unable to say wether a 
given blood pressure is abnormally high or low for the individual. Hypertension is no more than a symptom and although the nost common oanse of a consistent eleration in blood pressure is ossential hypertension, there are a number of other pathologie states which are regularly attended by increased arterial pressure. Bssential, or nonrenal hypertension in man is a conotitutional, familial and hereditary disease of unknown etlology (Rohberg). Thore are certain rare eauses of aforsistently elevated systolic and diastolic blood pressure resulting from extra-renal factors, such as ouprerenal tumors, basophilic adencmas of the pituitary gland, load poisoning, toxemis of pregnancy, increased intracranial tension, and bulbar pollomyelitis, but the vast majority of cases of persistent hyportension, not rosulting from renal disease, are of unknown etiology.

The term essential hypertension must be interpreted to indicate a symptom complex rather than a disease ontity, and it is probable that as medical knowledge increases, distinot types of oases will be soparated frem the min group on the basis of speciflo etiologic factors. In essential hypertension both the syatolic and diastolic blood pressures are increased. Tests of renal funotion, in the early stages, give nornal results, but as time pasees, a progressive diminution in funotion frequently is recorded, and a certain number of patients, probably not more than 10 per cent of the entire group, ultimately die of uremia. Cardise ocmplioations, suoh as congestire heart failure and coronary artery disease, are of nuch greater elinical importance and are the eause of death in approximately 60 per oent of all patients, while cerebral vascular acoidents constitute the terminal erent in 15 or 20 per cent of the cases. Wunerous attempts have been made to explain thettology of essential hypertension. These hare invelved rarious types of experinontal approach 
using the humen subject with essential hyperteneion, and also many offorts aining at the produotion of experimental essential hypertension in animals. In goneral, these inrestigations hare taken one of three main theses as tharotiology, vis., (a) humoral, (b) nerrous, and (o) renal. I. BUMORAI

The discorery by Oliver and Sehafer(14) of the profound effoot of extracts of the oupraronal glands upon the blood pressure of aninals, led to the hope that in this reaction was to be found the explanation for the maintenanos of blood pressure, and that disturbanoes of this glandular funotion could acoount for abnormalities of pressure, and so, intentigators hare endeavored to produce a hypertension experimentally by the injection of pressor oubstanoes into eninals.

4. Bpinephrino. Bpinophrine modifies the blood pressure by nodifying the annacter of the peripheral eiroulation. Then it is injeotod intrarenously there is a prempt inossase in blood pressure. This is brought about by tho direot action of the drug upon the rasoconstriotor norve endings, producing a constriotion of the arterioles and thus raising the periphoral resistence. The most pronounced offect is to be seen experimental iy in the ressels of the spanchnio area. On the other hand, an extract of the posterior lote of the pituitary gland produces a rise in blood pressurg aoting direotly on the mooth musele of the arteriolos.

In order that the hypothosis of glondular dioturbanoes as an etiologioal faotor in the produotion of abnormal blood pressure be proron, it was demed novessary to demonotrate the presenoe of epinophrine in the blood plasma, and, further, to show that this raried in mount with changes in the arterial pressure. Tho work of Stewart(15), Park(16), Hoskins and YoClure(17) 
Trandelenburg(18) and others, Indieates that the amount of epinephrine in the general oiroulating blood is infinitesimal. On the other hand, Sohur and Folsel(19) thought they had demonstrated the prosonce of an excess of epinephrine in the blood of hypertensive patients, because serum from suoh individuals, oren in comiderabie dilution, causeldilation of the pupil of the enucleated frog's oyo (Meltzer-Ehrmann reaction). However, $0^{\prime}$ Connor (20) and other: have som that this reaction is not epecific for epinephrine, but it is also given off by substanoes arising in serun after the olotting of blood. In the plasma of the blood from the adrenal rein, there is a conoentration of epinephrine from $1,1,000,000$ to $185,000,000$. In peripheral blood, eithor renous or arterial, 0'Connor(20) found that opinephrine cannot be demonstrated. Fulse(21) working^ the Volhard Clinic, found a frog perfusion preparation sensitire to a ooncentration of epinephrine of 1:790,000,000. He found no response of an epinephrine-1ibo oharaeter, howerer, with serum or plasma of normals or essential hypertensives either with renous or arterial blood. On the other hand, if opinephrine was injected, then the serm did as aume raso-constricting proper1ies. He also found a sensitising substanoe in the blood of nephritio hypertension for epinephrine. Kure(22) et al, using very delicate chemioal methods, hare suooeeded in detecting opinophrine in normal human arterial blood, in a conoentration of 122,000,000. In cases of essential hypertension, concentrations of two to three times this mount ware found.

Mthough the experimental evidenoe in favor of epinephrine playing an important role in the maintenanoe of normal vasoular tone is very doubtful, yot under certain pathological conditions of the gland, suoh as hypernephromay an inorease in rascular tone may ocour, but this is rery rate. on the whole, whilo a fow Investigators still adhere to the epinephrine theory of 
hypertension, it has been generally abandoned.

B. Pituitary Gland. Putracts of the posterior lobe of the pituitary body hare atrong pressor action, but the experimental ovidence in favor of the pituitary in the maintenance of normal blood pressure, or its effect as an etiologioal agent in essential hypertension is rery sperse. Leindorfer(23) injected pituitary extract intraspinally into cats, but the results were inconclusire. Mononder(24) and Menonder and Braum(25), found that dogs deprived of their hypophyses have s lightly lower blood pressure than normal, and they postulate that the lack of secretion from the anterior lobe influences the vasomotor mechenism. Cushing(26) obderved a heary infiltration of basophilic elements in the posterior lobe of fatal eases of oclampsia, and ossential hypertension, and he concluded that the source of these hypertensive disorders lay in the posterior lobe of the pituitary body, that the extent of basophilic invasion from the pars intermedia was a measure of posterior 1obe activity and that it represented the histopathologio basis of eolanpsia and essential hypertension in young persons and may possibly be etiological ly related to the atherosolorosis of old age. Kylin(27), on the basis of observations that two illnesses, Simond's disoase and essential hypertension, show opposite symptom complexes, thought that a part of the cases of essential hypertension might arise through hyperfunction of the enterior pituitary. From this observation, studies were made of the prolan exoretion in the urine of patients with hypertension, and it was show that individuals with inoreased blood pressure : excreted more prolan than those with normal pressures. Blount(28) observed the influence of additional pituitary anlagen on the oiroulatory system offthe developing urodele and found oondition paralleling hypertension in the mamal. There was marked rasoconstriotion, particularly in the ressels of the gills, forelimbs and oaudal fin, wich may result in 
stasis and obliteration of ressels. The general capillary bed mas reduoed, the heart rate was deoreased and there was rentrieular hypertrophy. Those some conditions hold for hypertension in the memal and this was the first experimental work wit oh definitely associated the pituitary with a possible hypertensive state.

C. Pressor lotion of Kidney Bxtracts. Almost all know urinary constituents have been considered by one investigator or enother to oause hypertension as a result of retention, in the organis, the evidenoe for each being - qually slight or entirely wanting. Urea, purine deriratives, werk aelde, sodium chloride, and the hypothetical toxin of uremia have been blamed but nerer convicted, since upon injection into experimental animals the results have been very unconvincing, to say the least.

Tigerstedt and Bergnann(29) showed that saline extracts of the kidney tissue of rabbits produced a sustained rise in blood pressure when injected into other rabbits, and so they suggested that hypertension in renal disease was due to liberation of a prescor ubstenoe, which they named renin, 28 a result of destruction of rental parenchyma. Other experimental evidence al ong similar lines has boen advenced by Hartwich(30). He found, as did Cash(3l) previously, that if branches of the renal artery of a dog were ligated and the appertaining kidney tissue underwant noorosis in situ, hypertension dereloped, while this did not follow ligation of the splenic artery. Hartwioh further found that the pressor effect of epinephrine was greater if the anthal was previously giren an injection of blood serum fran dog with renal tissue disintegrating in situ. On the other hand. Pearoe(32) showred that the pressor action of renel extracts varied in different animels 8 acording to him, the extract of $\operatorname{dog}^{\prime} s$ kldney produced a fall in pressure. J. L. and E. M. Miller(33) 11kewise did not obtain pressor effects from kidney extracts. 
D. Pressor Substances in Blood. Volhard (34) inoluded renal hypertension anong the varieties of high blood pressure that he considered due to the aotion of a pressor substance in the blood. His pup11s, Hulse and Strauss(35) oleined to heve demonstrated in the blood of patients with glamerulomephritis and oolempsia gravidaru a substance that sensitized the artorioles to opinephrine and thereby resultod in the arteriolar apasm. They originally belived the sensitiring substence to be peptone-likes more recently, Fulse and Franks(36) have considered the possibility that it is an anino-containing body. Bohn(87) another member of the Bolhard sohool, also olaimed to have demonstrated the presence of a pressor substance in the blood of individuals with glanerulo-nephritis, the malignant phase of essential hypertension, and -olampsia gravidarum.

Petrorsky(38) reported scme interesting experiments in which ho found, by perfusing a normal kidney with Ringer-Looke solution, that the perfusate contained a substence which exerted a pressor ection on the systemic ressels: and augnented the cardiac action. He could not olaim that this was specifle for the kidney, as he found a scowhat similar offect produced by perfusates of othor organs. The substanoe was thernostable and passed through a BerkofoldKerzen filter.

Danzer, Brody and Miles(39) obtained marked and sustained rise in blood pressure wen they injected into oats, desensitized to humen blood, unchanged hypertensive blood. Agataton(40) injeoted focal extract and also blood serw from patients with essential hypertension and oaused spasm of the retinal artery in rabbits, but did not find this vith normal serum. Woiser(4I) conflrmed the resulte of Bohn when he injected aloohalio blood extraots into cats from patients with pale hypertonsion and found rises in blood pressure up to $80 \mathrm{~mm}$. H8. Hentohnenn, furthernore(42) observed construction of the carterioles in rabbit when the ear was porfused with blood from hyper- 
tensire subjects. He also found that in rabbits whore hyportension was produced by tying the renal artery or by other methods, the amount of vasoopnstrictor substances increased.

On the other hand, Curtis, Monoreif and Wright (42) observed no partioular effeot when heparinized blood from cases of essential hypertension was injected into desensitized cats. Capps and Forris(44) fai lod to confirm the olaim of Bohn that inoreased mounts of eiroulating substanoes were responsible for "pale hypertension". Loiter(45) observed pressor effeots in the rat when hoparinized plasma was injeoted, but these effects were independent of the type or eren the presenoe of hypertension. Hypertensive plasmas did not inerease the response of the blood pressure of the rat to mininal effectire doses of epinephrine.

Finally, Page(46) has reported that human blood, cerobrospinal and ascitic fluid from essontial hypertensives yoeld extracts with aleohol, whioh are raso-pressor. The reso-pressor aotivity was found to be dependent on the funotional intactness of the oentralfnervous system. If the corebro-spinal axis is serered below the midbrain, then the effectiveness of the extract is abolished in elerating the arterial pressure of anesthetized oats. Plekering(47) and othess, have found that the changes in arteriel pressure produced in reoipients by transfusion of blood fram donars with essential hypertension were rery amall and no greater then those produced by transfusion of an equal volume of blood from normal people.

Major(48) has adrocated the view that the oause of hypertension was the retention of guenidine bases. He believed that guanidine derivatives were normel urinary constituents, and that the excretion of these substanoes was diminishod in hypertension. Injection of guanidine derivatires into experinental animals produced a marked and sustainod rise in blood pressure. 
Injor and Wober(86) produced a rise in blood pressure of $40-50$ me. Hf. in doge by the injection of methyl-guanidine, and they postulate the guanidine basis as an otiologioal factor in hypertension.

Groomwald(49) and White(50) did not belleve that there was eatisfactory evidenoe that guanidine was excreted in normal urino.

Pago mado alcoholic : extracts of the plasma of dogs with hypertension produced by the Goldblatt technique, and injeoted it into anosthet1zed cats, but obtained no greater rises in blood pressure than with extracts from normal aniwals. Then the hypophysis was removed fram such hypertonsive doga it was found that the chareoter of the pressor respones to extracts of the plasmal was not altered.

(F). Cholesterol. Cholesterol is another product of metaboliam which has been considered posaible otiological factor in the production of hypertension. Insamuok as Westphel(52) found that hyperwoholesterinemia was present in 71 per cont of esses of essential hypertension. Fishberg(1), however, stated that hyper-oholesterincmia was rarely striking in essential hypertension, and Buerger(53) found no relation between the oholesterol content of blood and blood pressure. Experimentally, Fahr(54) Van Leersum(55), Sohnidinann(56) and Sohonheiner(57) heve all reported an inorease of blood presenre and blood cholesterol in rabbits, oocuring with arterio-sclerosis following the prolonged foeding of cholesterol in oil, or of substances high in cholesterol. There appears no doubt as to the production of arterio-solerosis but there is a doubt as to the value of the blood pressure readings. Shaptro and Seloof(68) confirmed the production of the arterio-selerosis but oould not substantiate the inerease In blood pressure. Thomas(87) described rises in blood pressure in rabbits by the repod ed injection of eholesterol, but Tholldt(88) oould not oonfirm this. 
II. MERVOUS

The wldespread rasooonetrietion that is present in arterial hypertension is an evidence of disturbanoe in the normally harmonious interaction of the different vascular territories. This has been show by the important investigations of Horing(59) and his pupils. Hering's studies wore initiated by the observation that sloring of the pulse after pressure on the side of the neck was due, not to mechanical stimulation of the rague as had long been beliered, but to a reflex engendered by pressure on the bifuroation of the common oaretid artery. Where the comon earotid dirides into the external and internal carotids, there is an mpulla-like dilation wioh Hering has termed the carotid sinus. In the walls of the carotid inus are nerve ondinge, the mechanical stimulation of which, initiates a reflex that lowers the blood pressure and slows the heart. Hering found that the sensory nerres leading from the proximal aerta-long knowhespecially in the rabbit, as the depressor nerre, but whioh he termed the aortic nerres-and the carotid sinus nerves together foom a unified aystem that serves to provent excessive rises in blood pressure. For this reason he termalthis system of nerves the "blood pressure restrainer" (Blutdruckzugler). Hering has shown that if the blood preseure restrainers are out in rabbits and dogs, otriking arterial hypertension results. His pupils Kooh and Kies(60) have maintained continuous hypentension and tachyoardia in rabbite and doge by this neans for one and a half year 8 Radiographio and anatomical studies of the rabbits rerealed dilation and them hypertrophy of the heart and there were also arterial and renal lesions. Hoymans and Bouckeert(61) oonfirmod this work and obtained pressures up to $250 \mathrm{~m}$. Hg., by direct arterial punoture, some of their entmels dying suddenly of aoute pulnonary edema. Kremer, Wright and Scarff(62) observed a moderate rise in blood pressure, fram $95 \mathrm{~mm}$. Hg. to $115 \mathrm{~mm}$. Hg., on unilateral dener- 
ration, but following bilateral denervation they found a persistent mariced hypertension up to $160 \mathrm{men}$. Hg., with degenerative changes in the aorta and fibrosis of the heart. However, Green, DeGroat and McDonala(63) noted only a transient elevation of blood pressure which at first was unstablo, and then later tended to become stabilised at a level not greatly above normal. Thoy did observo taohycardis in dogs, and suddon death from cardiae failure at times cocured, following complete denervation of the depressor systen.

Pursuing a somenhat different $\operatorname{course}$ of investigation, De Jaegher and Van Bougaert(64) produced a genoralized arterial hyportension by elootrioal stimulation of the floor of the third rentriele of dogs in aoute experimente. Horf and Urban(65) found that following injury to tho corpora namillaria, there was, at first, a fall in blood pressure which returned to the normal level after a few days. In one or two months a very considerable inorease in blood pressure ocoured, especially under the influence of exoitement, and after four or fire months, there was a permenent rise in blood pressure of forty to sixty m. Hf. The objeotion to these mothods is that they apave $^{\circ}$ no o ounterpart in essential hypertension, as found in the human.

III. REMAL

The kecognition of the association of renal lesions with signs of rasoular hypertrophy led to a porsistent idea that hypertension and nephritis wore always assoolated. Tho production of hypertension through injury to the lidneys has always beon considerod a possibility, and as a consequenoe, a numbor of workers have attempted to answer this question by reducing the wount of functional. kidney tissue in the following ways: (a) Obstruction to urinary flow; (b) Reduction of kidney substance by excisions (o) Destruction of kidney substance by X-ray; (d) Production of renal congestion; (e) Produetion of renal ischenia. On the whole, until lately, the results of 
those various methods have been conflioting and in many instanoes have been open to question.

a. Obstruction to Urinary Flow. A number of observers have atated that the experimental production of urinary obstruction by ligation of the ureters was followed by hypertension and cardiac hypertrophy. This was first done by Bockmann(66) in 1857, who ligated one ureter in a dog and four months later thought he found left ventrioular hypertrophy. However, Koellioker(67), the great contemporary anatomist and pathologist, examined the pooinen and questioned the existence of hypertophy. Later, Strauss(68) olaimed to here produced cardiac hypertrophy in guinea-pige by obstruoting one ureter for periods of from four to six months. Huoh more convinoing are the experiments of Rautenberg(69). He blooked one ureter in rabbits for throe woeks, then removed the obstruetion and extirpated the other kidney. The urine remained albuninous. He observed the animuls for periods up to twenty-one months. The blood pressure rose as high as $170 \mathrm{~mm}$. Hg., the normal controls haring been 122 .m. Hg., or less. In dogs, Hartwioh(30) has observed hypertension within three hours after the 11gation of one or both ureters. b. Reduotion of Kidney Substanoe. Passler and Heineke(70) in 1905, first romoved half of one kidney in series of dogs. Four weeks or more later the intact kidney was remored. At a subsequent operation, another piece of the kidney operated first was reseoted. This was repeated one or more times at long intervals, so that as many as $81 x$ operations wore performed. They found a rise in blood pressure (arerage $21.5 \mathrm{~mm}$. Hg.) by direct cannulation of the femoral artery, and cardiae hypertrophy (up to 67 per cent), that paralleled the time the animals lived in a state bordering on renal insuffiolenoy without cachexia. With cachexia the blood pressure fell. Bainbridge and Beddard(71) in 1907, removed three-fourths of the kidney tissue in oats and found that a 1088 of more than 75 per cent of the kidney 
tissue oaused an increase in nitrogen output, as seen in starvation, but the effeot on blood pressure was queationable. Pearse,(72) In 1908, ocnfirmed the work of Bainbridge and Boddard(71). Janewg (73) out off part of the blood supply to the kidney of the dog by ligating some of the branches of the renel artery, and obtained a rise in blood pressure of betwoen 40 and $50 \mathrm{~mm}$. Hg. Pikcher(74) also ligated some of the branches of the renal artery of the dog, but did not obtain a rise in blood pressure or cardiac enlargement. Anderson(75) likerise, did not note any -leration of the blood pressure after removal of large portions of the lidney substance in rabbits, sufficlent to product signs of ronal insuffiolenoy. Cash (31), carried out geries of experiments on dogs in which he either separated part of the kidney from the main mass, or cut off the blood supply. Ho found that an inorease in blood pressure, (particularly the diastolio), occured only if he left the necrotic tissue in situ; otherwise no ohange was noted. This inorease was maintained for a few days and then roturned to narmal. This rien is controverted by the experiments of Paossler and Holnoke(70) who did not leave any necrotic renal tissue, but nevertheles: producod hypertension, and by the findings of Janoway(3) that hypertension persists long after the necrotic parts have been oonverted into fibrous soars. Allen, Soharf and lundin(76) reduoed the funotionel kidney tissue to 25 per oont of its original amount, and obtainod inoreases of 80 to $30 \mathrm{~mm}$. Hg. In blood pressure, but produoed renal insuffioienoy. Mark(77) ligated both renal arteries and obtained a rise in blood pressure before the animal died of renal insufficlenoy. Kark and Geisendorfer(78) ligated one renal artery and subsequently removed the other kidney and observed a rise in blood pressure with scme cardiac enlargement in their series of aninals. Ferris and Hynes(79) remored one kidney, then Itgated the other main renal artery 
and found a rise in arterial blood pressure with a subsequent gradual fall. Apfelbach and Eensen(80) injected charcoal into the renal artery and produeed renal insuffioienoy as a result, but no hypertension. Friedman and Waohsmuth(81) ligated the renal artery or some of its branches and found a hypertension persisting for one or two weeks. After resection of the kidney or extirpation of one kidney the blood pressure rimained unohanged or fell somewhat. They did not observe a progressive rise in blood pressure or a lasting hypertension. Chanutin and Ferris(87) obtained hypertension and renal insufficioncy in rate following partial nephrectony. Wood and Ethridge(83) confirmed Chanutin and Ferris by noting chronio progressive glemerviar and arterial renal lesions assoolated with hypertension produced by subtotal nephrectomy in rats. Pick(84) romoved three-fourths of a dog's kidney tissue and observed a rise in blood pressure. Then 20 oo. of the hypertensize blood was injeoted into a second normal dog, there was an Imnediate rise of blood pressure in the latter animal which stayed up for several days. Now when 20 oc of blocd from a third dog, whose kidneys hare been simply denervated, was injected into the second dog, its blood pressure becme lowered. Other methods of roduotion of kidney substance inolude the injection of rarious substances through the renal artery in an endearor to demage the kidney to en extent just short of urenie, or to cause a blockIng of the maller ressils in the kldney. Rafsky, Bernhardt and Rhodenberg(86) injected tranium nitrate repeatedly and produced nephritis and hypertension. They also injected cholesterol, Viosterol and aspartio acid with similer results. Other rorkers have injected such substanoes as finely divided charcoal and kaolin to produce rises in blood pressure.

Bilateral nephrectomy is such a shooking and rapidly fatal operation that one would not expect any considerable hypertension during the short 
tenure of life of the animals. However, Mosler(89) did succeed in keeping 13 rabbits alive for forty-eight hours after the removal of both kidneys. He observed a rise in blood pressure in all but two, but Backmann(90) was unable to confirm those results and Hartwich(30) also noted only an insignificant rise in pressure after bilateral nephrectomy in dogs. o. Destruction of Kidney Substance by $X$-rey. A third way if injuring the kidney was used by Hartman, Bolliger and Doub(91). They produced in dogs extensive destruction of the renal parenchyma wth replecenent fibrosis and vascular sclerosis by the application of high voltage Roentgen rays to the kidneys. Consistent rise in blood pressure with hypertrophy of the left vantricle was observed in the radiated animals, which were followed bor many months. Pago(92) produced nophritis and hypertension in dogs by transplanting the kidneys to a subcutantous position and irradiating with $x-r a y$. d. Production of Ronlal Congestion. Bell and Pedersen(93) produeod chronio renous congestion of one kidnoy in the rabbit by putting on aluminin band around the renal rein and at the ome time preventing development of oollateral ciroulation with a snug membrane around the kidney. They reported a well marked hypertension of protracted duration. Menendez(94) placed a ligaturo on the renal vein so as to reduce its calibre without oompletely closing 1t, and produced a rise in blood pressure of over $20 \mathrm{~mm}$. Hg., which began two weoks after ligation and lasted more than two months. In enother series of animels the kidney was denervated at the time of obstructing the rein and in none of these did he observe rise in blood pressure.

- Production of Renal Ischemia. All these methods of producing the erterial hypertension suffer frcm one of two faults either the eleration in pressure is not persistent, or the animals die of renal insufficiency. In 1934, Goldblatt, Lynch, Hanzal and Summerville(95), in a now classio experiment, for the first time sucoessfully produced persistent arterial hypertension 
without renal insufficiency in animals. This was accomplishod by establishing chronic reduction of the flow of blood to the kidneys. Eleven healthy dogs were prepared with one carotid artery looped through a short tube of skin, after the method of Van Leersum(96), to permit aocurate observations of systolic blood pressure at frequent intervales blood chemistrya studer urinanalyses wore made to rule out the presence of renel disease. Systolic blood pressure readings were taken daily for at least two months to establish control levels, The animals wore then operated on under aseptio conditions, and adjustable silver clamps were applied to tho renal arteries. In some of the animals conotrietion mas made great at the boginning, wilo in others it was made moderate at firat and subsequently increased one or more times. Constriotion of one renal artery was fol lowed by a moderate or slight rise of pressure, which tended to return to the level of the control period. Following the produotion of bilateral renal isohemia, however, the systolic blood pressure rose to a variable degroe in all animals. Pressures persisting between 200 and $240 \mathrm{~mm}$. Hg . were common; sowe approached $300 \mathrm{~mm}$. Hg. In two of the animals the clamping of both renal arteries was made almost complete from the beginning; the rise in blood pressure that followed was accompanied by the development of uremia, which rapidly proved fatal. In these animals the amounts of urea nitrogen, total nonprotein nitrogen and oreatinine in the blood increased progressirely, while the urea clearance and the output pf phenolsulphoneptialein deoreased progressively until death. The remaining anlmels survived for long periods, up to as long 28 three years. In only few of these animals did tests reveal any deorease in fidney function. In che animal showing a persistent eleration of blood pressure for more than fifteen months, the urea olearance was reduced to about 50 per cent. of the mean oontrol level. In others, however, either no change 
occured in urea clearanee or only slight preliminary reduction, with rapid return to normal. The concentrations of urea, total nonprotein nitrogen, creatinine and guenidine in the blood all remainod within normal 1inits. Goldblatt and his associates, also intestigated the effects of conotriction of the splento and both femoral arteries in one animal and of extirpation of one suprarenal gland with denervation and destruction of the medulla of the other in a second dog; neither of these procedures had any significant effect on blood pressure, which rose in both instances after constriction of the renal arteries. Ischemia limited to the kidneys appears to be a sufficient oondition for the production of a persistently elevated systolic blood pressure. The hypertension produced by this moans rosembles closely that associated either with so-0alled benign nophroscler osis (essential hypertension), or with so-callod malignant nephroselerosis (nalignant hypertension) in man, depending on whether the constriction of the arteries is moderate or serere.

Goldblatt has also produced persistent elevation of systolio and diastolic blood pressure by renal ischemia in the macaque monkey, an animal more elosely related to man than is the dog. This was a furthor atep in the chain of analogies between the hypertension induced in dogs by renel ischemia, and that wich is assooiated with renal arteriolar disease in man. The Goldblatt technique has afforded a now approach to the investigation of the problem of hypertension under controlled experimental conditions, and attempts to eluoidate the pathogenesis of this particular type of experimental renal hypertension have followed these general lines:

(1) Afferent impulses from nerve endings in the ischemic kidneys passing to the rasomotor center might result in reflex generalized rasoconstriction and consequent eleration of blood pressure. Complete denervation of both 
kidneys bofore the application of the Goldblatt clamps, would give some -lue as to the existence of suoh impulses. Page(97) unilaterally nephrectamized dogs, subsequently constricted the renal artery with the olemps and then seotioned the extrinsic renal nerves by oarefully otripping the renal pedicle. He observed a sharp and ustained arterial hypertension, regardless of whother the kidneys had been denervated or not. Page and Heuer(98) in a - Iinical study, performod bilateral renal denorvation in a patient wth essential hypertension unoomplicated by deteotable renal incolvment, and did not find any change in the level of the arterial blood pressure. Elaut(99) repeated Page's work(97) on dogs and obtained the same results. Yore recently, Goldblatt, Gross and Haneal(100) observed that in doge, excision of the thoracio portion of the splanohnic nerres and the lower four dorsal sympathetio ganglia on both sides, does not prevent, oure nor permanently lower, in any degree, experimental renal hypertension produced by renal isehemia. These resulte demonstrate that the extrinsic nerve supply to the kidney does not participate in the genesis of renal hypertension, either reflexly or otherwise.

(2) Afferent impulses from the ischemic kidneys might in some way bring about inereased output of some internal seoretion, whioh, by peripheral or central action might effect generel rasoconstriction and thus raise the blood pressure. Goldblatt(95) showed that the suprarenel medulla probably plays no part in the pathegenesis of this experimental hypertension in dogs. He remo red one suprarenal body and destroyed the medulla of the other suprarenal after sectioning the splanchnic nerres on that side, and found that the blood pressure rise was not interefered with. Page(101) found that hypophysectany in dogs with hypertension produoed by renal ischemia (mothod of Goldblatt), teduced arterial blood pressure to about normal levels, and it reduced slightly the blood pressure of normal dogs. Preliminary hypophysectany did not prevent 
the rise in blood pressure establishod by renal ischemia, but the rise was transiont.

(3) Same now substance might be transmitted humorally via the blood to effect the generalized rasoconstriction responsbble for the hypertension. Renal insuffieiency with acounulation of urea, oreatinine and total nomprotoin nitrogen in the blood, may produce an elevation of blood pressure, but the animals soon d10(70). Furthermore, hypertension in doge with renal ischemia is unacoompanied with ronal insuffioionoy, as Golabatt(95), Page(97) and others have repeatedly shown. Herrison, Blalock and Mason(202) prepared saline extracts from ischemic kidneys of doge rendered hypertensive by partial obatriction of the renal arteries or by ligation of the ureteres. They found that these extracts oaused, first a prelininary sijht decline and a secondary marked rise in blood pressure in normal, anesthetized dogs. Pringmetal and Friedmen(103) confirmed the results of Herison ot al, using similar kidney extracts fron fourteon dogs with experimental renal hypertension and from fifteen hypertensive patients, whose kidneys were obtained at autopsy.

Furthermore, attempts here been made to demonstrate pressor aubstanees in the blood of these hypertensire animal s. Dicker(104) has produced a temporary rise in blood presgure in anesthetized dogs following the injection of an alcoholic extract of the serve of three hypertensive dogs, wile sinilar extracts of normel doge did not here this effect. Page(105) however. Injeoted alcoholic extracts of the blood plasma of dogs with hypertension Into anesthetized cats and found that there was no higher eleration in blood pressure then with extracts obtained from normal dogs. Prinametal and Friedman(106) perfused the tails of hypertensive dots alternately with their own hoparinised blood and with blood from normal animals and found a dopressor 
offect with the hypertensive blood, as compared to the normal blood. Collins ad Hoffbauer(107) transfused blood from dogs with hypertonsion cansed by the constrietion of the renal arteries into normal dogB and obserred no eloration of blood pressure.

In order to aid in the elucidation of the mechanism responsible for the production of experimental renal hypertension in dogs, it was considered worthwile to study the effect of certain representative depressor and pressor drugs, acting eithor oentrally or peripherally, in a group of animals with this form of hypertension. It was felt that a comparison of their effeats in experimental renal hypertension with their already knom action on the blood pressure in clinicel essential hypertension and in normal animels and humens might be of ralue in this regard. The work reported here, therefore, was undertaken with this objective in mind. 
YATERIAL AND METHODS

Dogs of mixed breeds were used. The animals, all males, raried in age and weight, although all weighed over $10 \mathrm{Kg}$. Their exact ag॰ was not lmown, but they were 211 full grown, seomingly normal dogs. They were kept in individual, roomy, sanitary steel cages and fed throughout the entire experimental period on a oomercial dog food, with freah raw meat and bones onoe a reek. This diet was adequate to maintain the dogs in a state of good nutrition. The mount of water was not limited.

They were put thru a control ported varying frem one to throe months during wich time temperature, pulse and respiration as well as blood pressure were taken twice a woek. The weight was rooorded once a week and ocoasional blood chemistories and urinanalyses wre done, which invariably wore found. to be normal.

The temperature gave an indication of any disease process whioh may have been present, or was beginning to develop. If this oocured the dog was immediately isolated and discarded, if necessary. The pulse and respiration were used as an index of relaxation for the dog. Inamuoh as the blood pressure was taken on the unanesthotised dog by means of direct arterial puncture, the slight pain of the needle priok would occasionelly disturb the animal during the early part of the training period, so that the pulse rate and respiration would rise due to the excitement, and higher values would be obtained for the blood pressure.

The acourate determination of blood pressure ohronioally and without trama in the trained, unanesthetized animal, has oocupied the attention of investigators for many years. As in humans, there are two gonerel mothode for taking blood pressures the indireot and the direot. 
The indirect method consists of a modification of the conventional sphygmomanomoter as used in humans, applied to some part of the body of the animal. Van Leersum(96) made four longitudinal incisions in the akin of a rabbit's neck, and enveloped the carotid with a flap. After heal ing had oocured, the artery in the flap was onciroled by a small sphygmonanometer cuff and blood pressure determinations wore made by palpation. This method gave systolic reading only. Jenerray (109) on spoeially selected nnanesthetized dogs, applied a modified Rira-Rooei(13) ouff to the lower foreleg of Hge dogs, and estimated syatolic pressure by palpation of the smaller arteries In the ball of the foot. Kolla(110), on anesthetized dogs, applied a sphygomanometer, oquipped with ofpocial typo of ouff which permitted conpression of the artery without diatortion of the $10 \mathrm{~g}$, and a sphygmograph of suffieient delloay to rocord the pulsations from on artery as small as the femoral. The systolio and diastolio pressures wore ostimated. Ferris and Eynes(111) used an ordinary sphygmomanometer, encireling tho thigh of a dog, and a phonendosoopie typo of atethoscope aplied to the artery, posterior to the medial epicondyle of the fenur, and determined the systolle and diastolie levels by the usual oriteria. Gaertner(112) applied his tonometer to the tall of the dog, and Trendelenberg(113) used the seme apparatus on the foreleg of the oat. Tononetric determinations are subjeot to the sme objections as In man, viz., that the oolor ohanges through the skin are very diffioult to distinguish and therafore, are not rery reliable or aocurate.

In general, there are a number of objections to the indirect method of determining blood pressure in dogs. There is the tondeney for the ouff to slip or buckle up, and the diffioulty of looating the small vessels of the foot and ankle and aocurately applying the stethosoope to then. The method is unirustworthy because of the inability of the operator to gorern the tonus of the museles or legs sinoe the animal "tightens up" when the ouff is inflated. 
Shivoring of the enimal may also introduce a similar orror in tho readings. It is very difficult to maintain the same constanoy in the selection of the correct systolic impulse below the cuff, and, at times counds cannot be obtained. Furthermore, in attempting to determine the diastolie level the sounds sometimes fade away rery gradually and may not disappear when the ouff is coupletely deflated. The ohief adrantages of the indirect, or ouff method, are the convenionoe in its ase and the absence of trauma. In the direot method of blood pressure determination, the artery is oither oannulated, or a noodle is inserted, and connooted up to a meroury or an aneroid manometer, or the reoording may be made optioal ly. (Frank(114), Wlggers(115), Henilton(116). Pavlov(117) trained dogs to lie quietly wilo he inserted a oanmula into a sull artery on the inner aspect of the knee joint of dogs without anesthesia. Brooks(118) anohored the carotid under the skin of the neok and recorded the pressures one to three days later, by inserting a cannula or a trooar. Trondelonberg and Flelschaure(119) prepared tho oarotids of rabbits and made readings after rocovery from anesthesia.

Dameshek and Lomen(120) desoribed an instrument for the direct determination of intra-arterial pressure in man whioh was ocmsidered to be suitablo for the determination of the mean arterial pressure in the trained, unanesthotized dog, and this method was used in the present atudy and w11l be deseribed later. Parkins(121) also used the Imeshok and Loman Instrument and ooneirmod Its acouraoy and advantages with the trained unanesthetised dog, partioularly in following the moan intra-arterial blood pressure at intervals oror a long period of time.

The training of the aninal was often easy, although a fer doge were so exoitable that scmo diffloulty was experienoed in making them lio still. This, of oourse, was more often enoountered in the younger animals, but, on the other 
hand these responded more readily to training. The actual training was more time consming than any other prooedure. I padded table with side supports was constructed so that the aninal would lie comfortably on ite back. I wide leather strap, whioh crossed the $\operatorname{dog}^{2} s$ obost and bound him dom securely, wa used in conjunction with two coft fabric straps, which acted to hyper-extend the hind logs. The straps rere looped around the ankle and tied to the lower ond of the table. A muzile, used at firot, was later disoarded in faror of an ordinary oollar, which was tied to the upper end of the table to prevent movement of the head. The dog was placed on the table for periods ranging from ten to thirty minutes, at about the seme time each day, for a week or two. While the animal wes lying still he was potted and spoken to gently, but attempts to got off the table were immodiately punishod. The dog was invariably fod following his roloase. On the second or third woek, the animal was atrapped down and the biwoekly obserrations wore commenced. After a rest period of a fow minutes the temperct ure was taken reotally in the uoual manner, and the pulse and respiratory ratesfore rocorded. If the aninal apeared agitated and the temporature, pulse and respiration were elevated, or any one of them was higher then ordinarily, further rest was allowed before the arterial punoture was made. This was important booause the blood pressure was taken only once for that day. The procodure of Dameshek and Loman(120) was used to obtain blood prossure readings. This consisted of a direot reading of the intra-arterial pressure by the introduction of a number twenty guage short berel needle into the femoral artery. The noedle was connected through a three-way stop-cook with a five oc. luer syringe and an aneroid sphygmomanometer. Then the noodle entered the femoral artery, the barrel of the syringe was pushod up rapidly and the systolie pulsations were seen. Then this oocured, the ralve on the 
stop-cook was turned and the blood allowed to flow towards the attached sphygnomamometer. Bntrance into the latter was prevented by a glass trap (originally supplied with the Beoton-Dickins on spinal fluid manoweter). The trap was used either empty or filled vith a solution of sodium citrate. When blood entered it, systolic and diastolic pulations becane apparent and the transmitted pressure imediately begen to be registered on the sphygmomemoter and the maximum pressure was obtained within a few seconds. The larger the needle used, the more rapidly was the maximue pressure obtained. With a fine hypodernic noedle (guage 27), the dial moved slowly to a maximum reading, which however, was almost identioal with that obtainod by a large (guage 18) needle. A cortain amount of fluctuation in reading wes obtined, the degree of fluctuation varying directly with the sire of the needlo, 1.0., the finer the noedle, the less the fluctuation. A wait of a fer seconds was made to see whether the maximum reading had been obtained, after which the ralre of the otop-cook was turned to the syringe and chock was made as to the presenoe of the needle in the artery, and the absence of coagulation in the needlo. The blood pressure readings were made after the fluctuations of the manometer attained a more or less constant range and an arerage of the highest and lowest point at that instant was taken as the blood pressure. This, of course, represented noither the systolic nor the distolic lovel, but a point midray, or in other words, the mean pressure was actually measured.

The actual punoture of the femoral ortery in large sized dogs was not diffloult, and with the development of technique, punctuxe of the artery was in almost all instances made at the first attempt. There was but rory slight pain involved in a rapid pumcture with a sharp noedlo and the emotional response on the part of the well trained animal was apparent ly extremely slight and usually absent. After completion of the readings, firm prossure was made 
aver the artery for several minutes which effectively prevented the formation of a hematoma. In the more hypertensive animals there was a moderate tendency for a hematoma to develop in spite of continued firm pressure.

After a control period of from two to four weaks, the dogs were subjected to a unilateral nephrectcony through a lumbar appuoach. The lumbar region was closely olipped and shaved from the tenth rib to the iliac crest, and from the vertebral opines to the midline. The dogs were fasted for twenty-four hours, previous to ope ration.

$\Lambda$ pre-anesthetic dose of morphine sulphate 15 mgm. was given subcutaneously. Sodiw pentobarbital $30 \mathrm{mgm}$. per tf. war used intrarenously for anesthesia. This ocmbination of morphine and sodium pentoberbital gave excellent relaxation for two hours, after whioh the animal began to react, In three hours he was usually quite arake and was able to drink water that was offered to him.

The operative procedure for nephrectcmy was carried out with strict attention to esepcsis. The shaved area was washed with groen soap and water, followed by ether, 70, alcohol and iodine, with a final application of $70 \%$ aleohol to remove excess iodine. After properly draping the field with oterile towels and sheots, the incision was made about two inches lateral to the oostoretebral angle, alonf a line parallel to the Vetebral colum, to the third or fourth lumbar vertebra. The fascia and muscles wero carefully divided and the lidnoy approached extraperitoneally. Tho peri-renal fat was then dissected away and the renel vissels and ureter identified, tied with doubled black silk, and out. Then the kidney was shelled out and delivered through the ineision. The peritonem in that situation is very thin and delicate and tears very easily, so it was usually necessary to place several sutures in the peritoneva. Then the muscle, fasoia, subcutenoous tissue and skin were sutured in layers with interrupted black silk. In seviral cases, infection occurred and the dogs 
died of peritonitis. Usually, howerer, the animals made an uneventful reoovery, and ate wellon the second or third poot-operative day.

The dogs were then carried along for a further control period follow Ing the nephrectony, during which time the blood pressure, pulse, respiration, temperature, weight and general appearance were recorded. At intervals blood chemistry studies, and urinanalyses were made and oye grounds were studied, but renal function tests were not done.

Thirty to one hundred and twenty days later, the animals were subjeoted to constriction of the artery of the remaining kidney. The preparation, anesthesia and surgical approach were identical to that employed for the nephrectomy, The renal artery was easily identified by palepation and it was isolated for about two centimenters, near its origin from the aorta, for a distance sufficient to permit the application of the clemp. 1 complete and detailed description of the clanp and the instruments necessary for its application, will be found in Goldblatt's publication(95).

The anount of constriction of the renal artery could not be exactly determined, but the constriotion was oarried to a point where a definite palpeble thrill was felt just distal to the olemp. This ensured renal oiroulation so that the animals did not develop urenia, yet there was sufficient constrico tion of the artery to cause renal ischemia and the development of a persistent hypertension.

When the hypertension had reached fairly constant level, which occurred in four to fivo weeks, the effects of the intrerenous injections of rarious drugs were observed. The drugs investigated were anyl nitrite, nitroglycerine, sodium nitrite, ether, sodium pentobarbital, histamine, phosphate, acetyleholine bromide, pituitrin, and epinephrine. 
The administration of the drugs was relatively easy. Anyl nitrite was given by inhalation by means of an ether cone. The drug was obtained in the usual form of "perles" (IIIly), each oapsule oontaining fire minums. The perle was pleced in a gause sponge and crushed just provious to its administration. Nitroglycerine, $0.1 \mathrm{mgn}$. per $K_{6}$, , was injected intravenously inte saphenous vein on one side or the other. The seme route was employed for

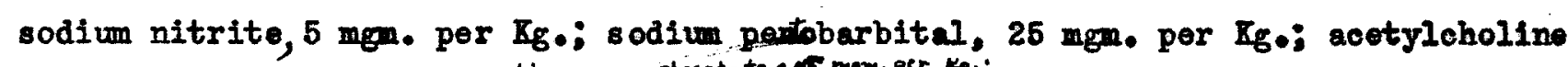
bromide, 0.05 mgm. per KB.iAPituitrin (P.D. \& CO. ), 10 pressor units per coj; and Adrenalin ECI (P. D. \& Co.), 0.01 mper K $\mathrm{K}_{8}$. Ether wes administered to these animals by the drop method to the point of surgicel anesthesia, and maintainod thero during the reading of the blood pressures.

The blood pressure was taken just previous to the intravenous injection of the drug, and the needle was permitted to remain in the artery during the ontire zesponse. It intervals, the needle was eleaned out with a stylet whon a olot formed, but the nedle remalned olear in most cases for about ten minutes. This procedure worked very satisfactorily for the observation of the action of 211 these drugs. 


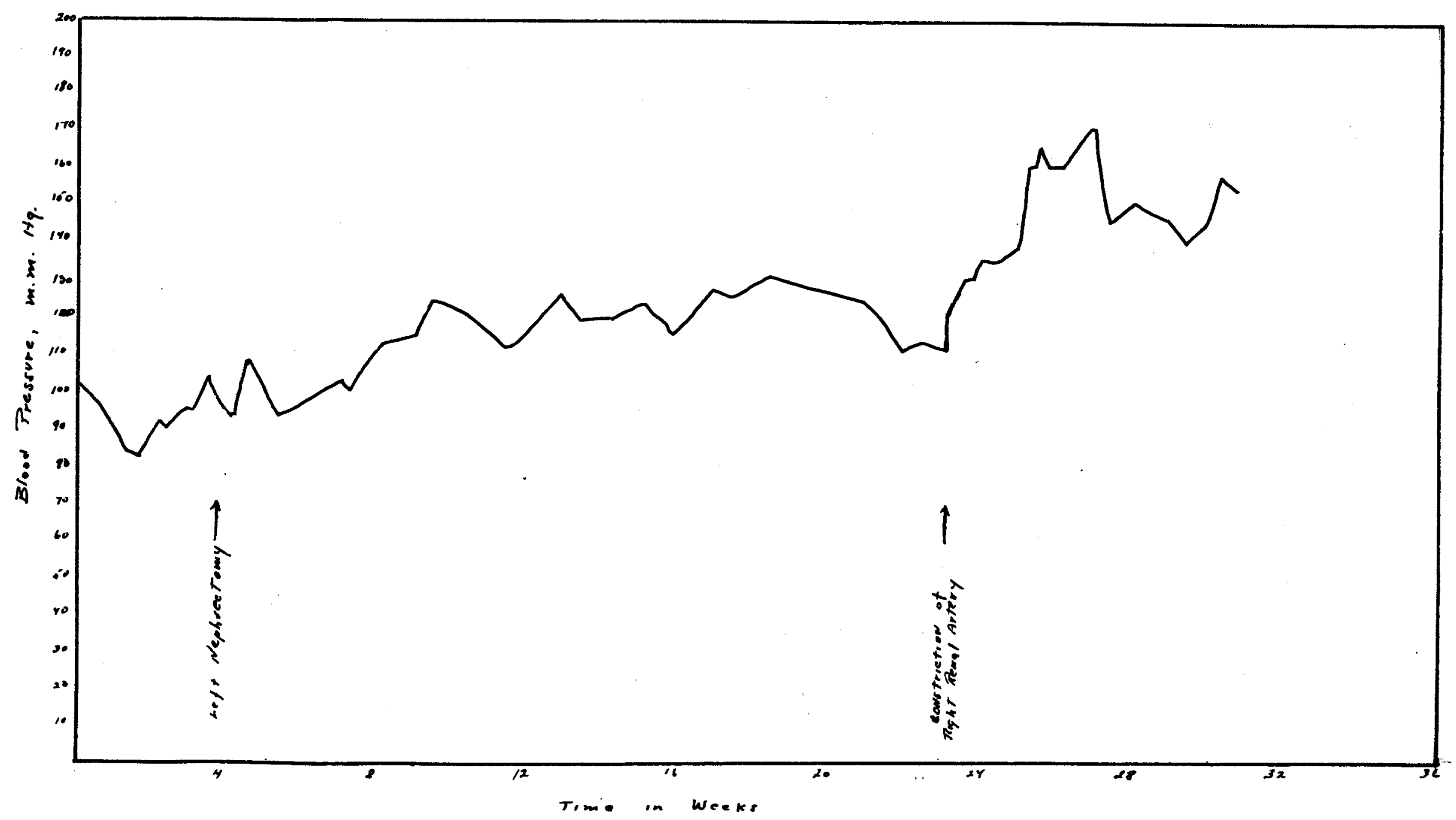

$$
\begin{aligned}
& \text { Figl. Dog 1-2 Blood Presure Following Left Nephrectomy and } \\
& \text { Subsequent Constriction of Might Penal Artery. }
\end{aligned}
$$




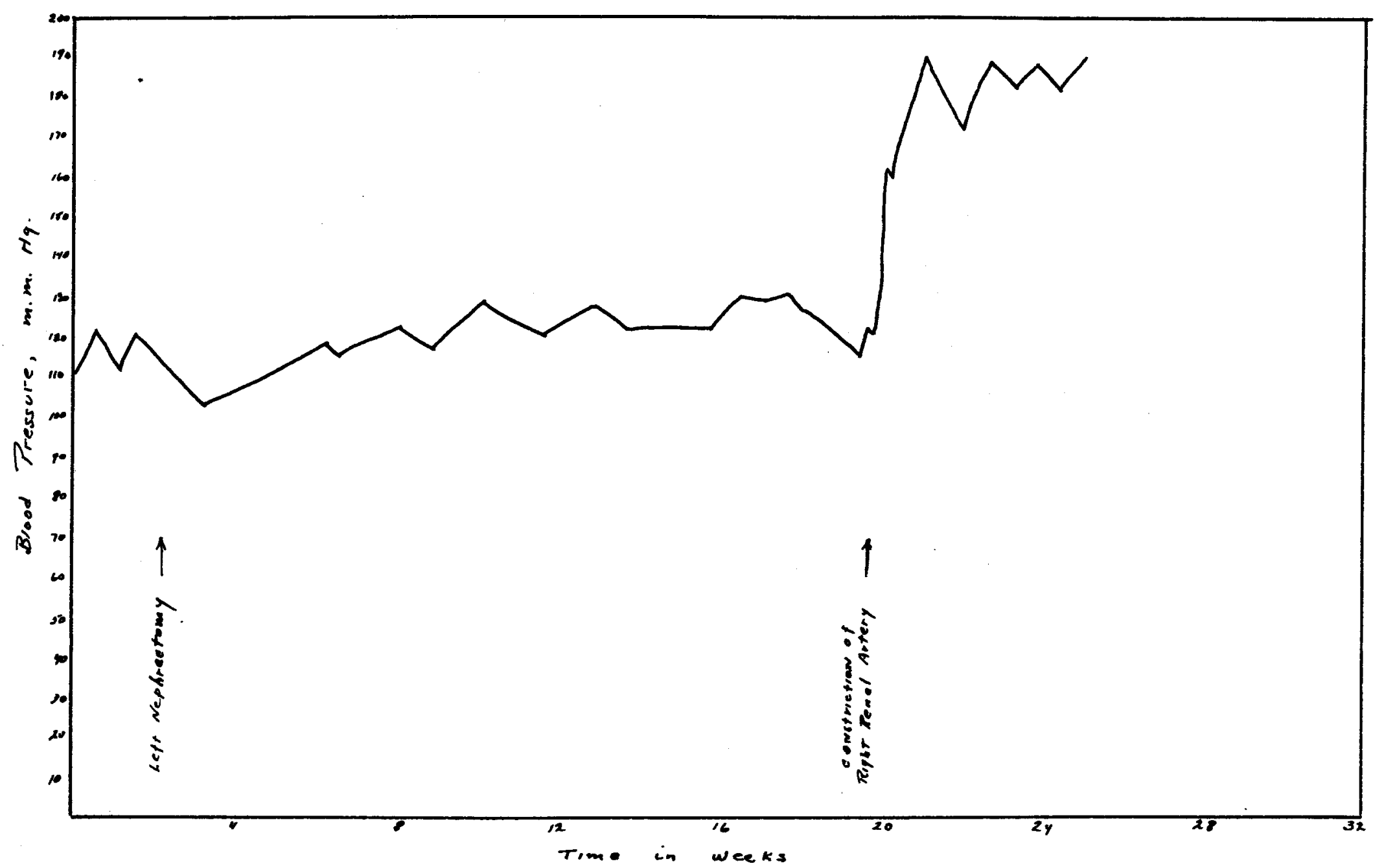

Fig. 2. Dog z-6. Blood Pressure Following Left Nephrectomy

and subsequent Constriction of Right Menal Artery. 


\section{RESUITS}

The blood pressure of these animals showed the following course. In animal 1-2 (FIg. 1), the average moan blood prossure in the oontrol period preceding nephrectomy was $95 \mathrm{~mm}$. Hg. Imediately following left unflateral nophreoteny, thore was a sharp drop wioh lasted for several woeks, with a subsequent gradual and sustained riso, conecmitant rith an incresse in wolght and an improvement inflegeneral ocoditioin An interval of fire months was allowed to intervene between nephrectomy and constriotion of the other renal artery, and during this time the average blood pressure was about $121 \mathrm{~mm}$. Hge Constriction of the right renal artery was done by turning the Goldblatt ol mp 315 degrees, so as partially to the Iumen. Thi induoed a rapid but moderate rise in bloed pressure fram a pre-operative lerel of $112 \mathrm{~mm}$. Hg. to $130 \mathrm{~mol}$. Hg. post-operatively, within twelve hours. Following thi there was more marked rise to 170 mo. Hg. within two or three weeks. The pressure level dropped approximately to $150 \mathrm{~mm}$. Hg. during the following month.

Animal 2-6 (Fig. 2), was nephrectcolzed after a control period of four weaks, during wich time the mean blood pressure about $120 \mathrm{~mm}$. H8. Ster a seoond control period of 16 wook with an arerage mean blood pressure of $125 \mathrm{~mm}$. Ho., constitetion of the left renal artery was done by turning the elamp 270 degrees from the open position. There was moderate, but immediate, rise of $22 \mathrm{~mm}$. Hg. in sixteen hours, and of $78 \mathrm{~mm}$. Hg. Within one weok. This rise has persisted for three woeks at an average value of $175 \mathrm{~mm}$. H8., but there have been rather wide fluctuations around this level. Dog 3-1 (Fig. 3), has had a somewhat shorter control period, but his blood pressure variations have been very similar to those described above. 


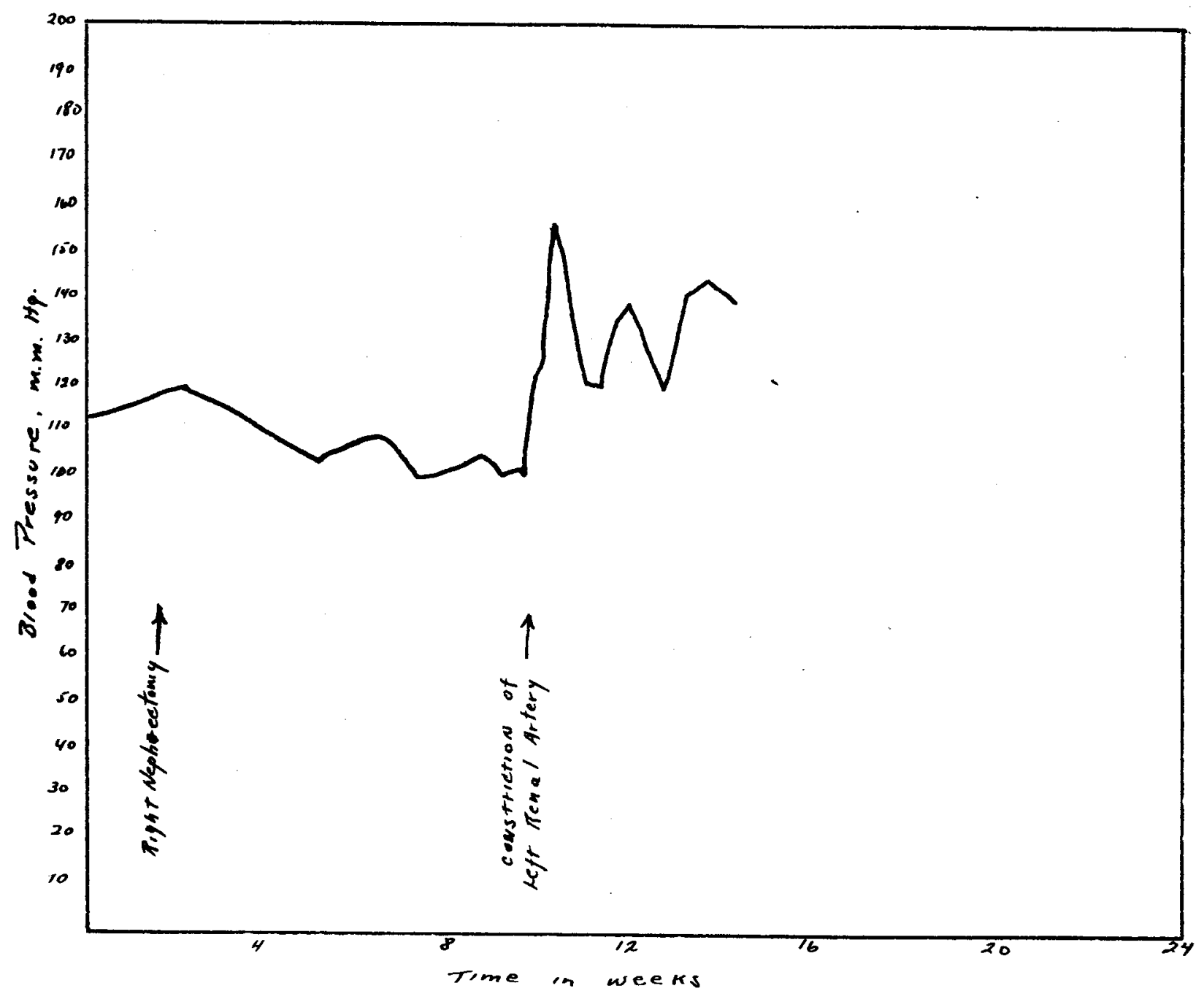

Fig 3 Dog 3-1 Blood Pressure Following Right Nephrectomy and Subsequent Constriction of Left Tienal Antery. 


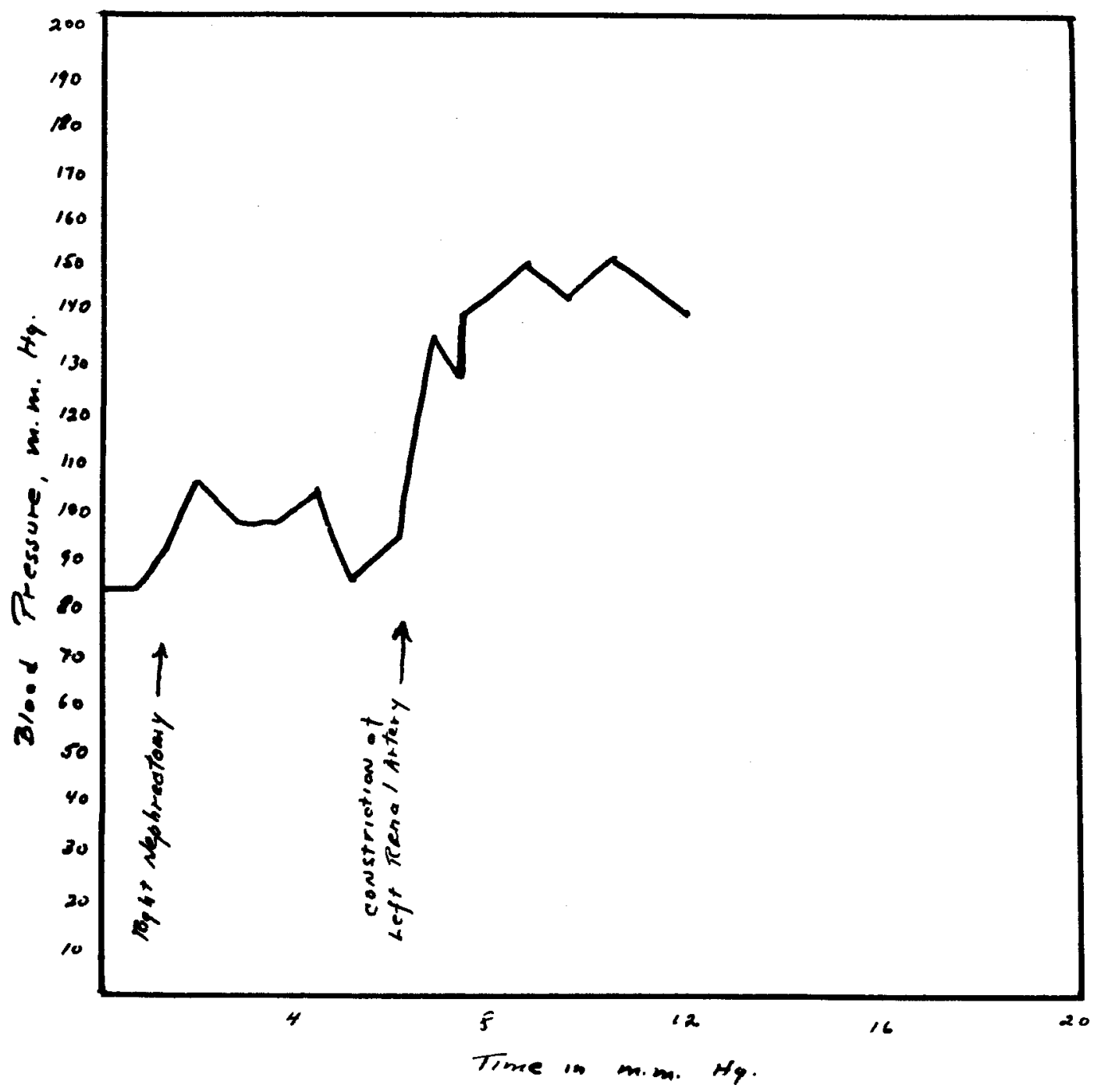

Fig 4. Dog 4-1 Blo0d Pressure Following Right Mbphrectomy and subsequent constriation of Lett Renal Artery. 
Since in the other two animals it was shown that nophreotomy produoed very 11tt10, If eny effect on the blood pressure, it wes dooided to shorten the control period previous to nephrectany and utilize the period subsequently as part of the control interval previous to constriction of the ronal artery. During the control period, the mean ererage blood pressure in this dog was $107 \mathrm{~mm}$. Hg., vith eluotuations of $20 \mathrm{~mm}$. Hg. Three months after the beginning of the control period, the left renal artery was oonstricted by turning the Goldblatt olamp 360 degrees. The blood pressure rose immediately, and in four deys attained a peak of $154 \mathrm{~mm}$. Hg. Following this, the blood pressure has fluctuated, but it has remained above the highest lovel reached during the control period.

Dog 4-1 (Fig. 4), has been subjected to the seme procedure with similar results to those in the animals previously mentioned. The prelininary control period was also shortened and canbined with the post-nephrectomy periode The arerage blood pressure for this interval was about $95 \mathrm{~mm}$. Hg.. vith minimum and maximu readings of 88 and $108 \mathrm{~mm}$. Hg. respectigely. Constriction of the lest renal artery was performed eight wooks after the comencement of the control period, and the olomp was tightened by two complete turns. The blood pressure soon rose and reached a peak of $138 \mathrm{~mm}$. Hg. on the second day. There was a brief drop on the tenth post-operative day, and a secondary rise ocourred which caused the pressure to $g 0$ up to $150 \mathrm{~mm}$. Hg., where it has remained for the past six weeks.

The results with the drugs studied were as follows:

1. Amyl Nitrite. Anyl nitrite elevated the blood pressure in al 1 these animals. In $\operatorname{dog} 1-2$ (Fig. 5), there was a brief rise of $25 \mathrm{~mm}$. H8. lasting for two minutes and then a subsequent fall in blood pressure to somem wat belew the original level for seven minutes. The blood preseure of dog 
Fig 6. The Effect of Amyl Nitrite on the Blod Pressure of Four Hypertensive Dogs.

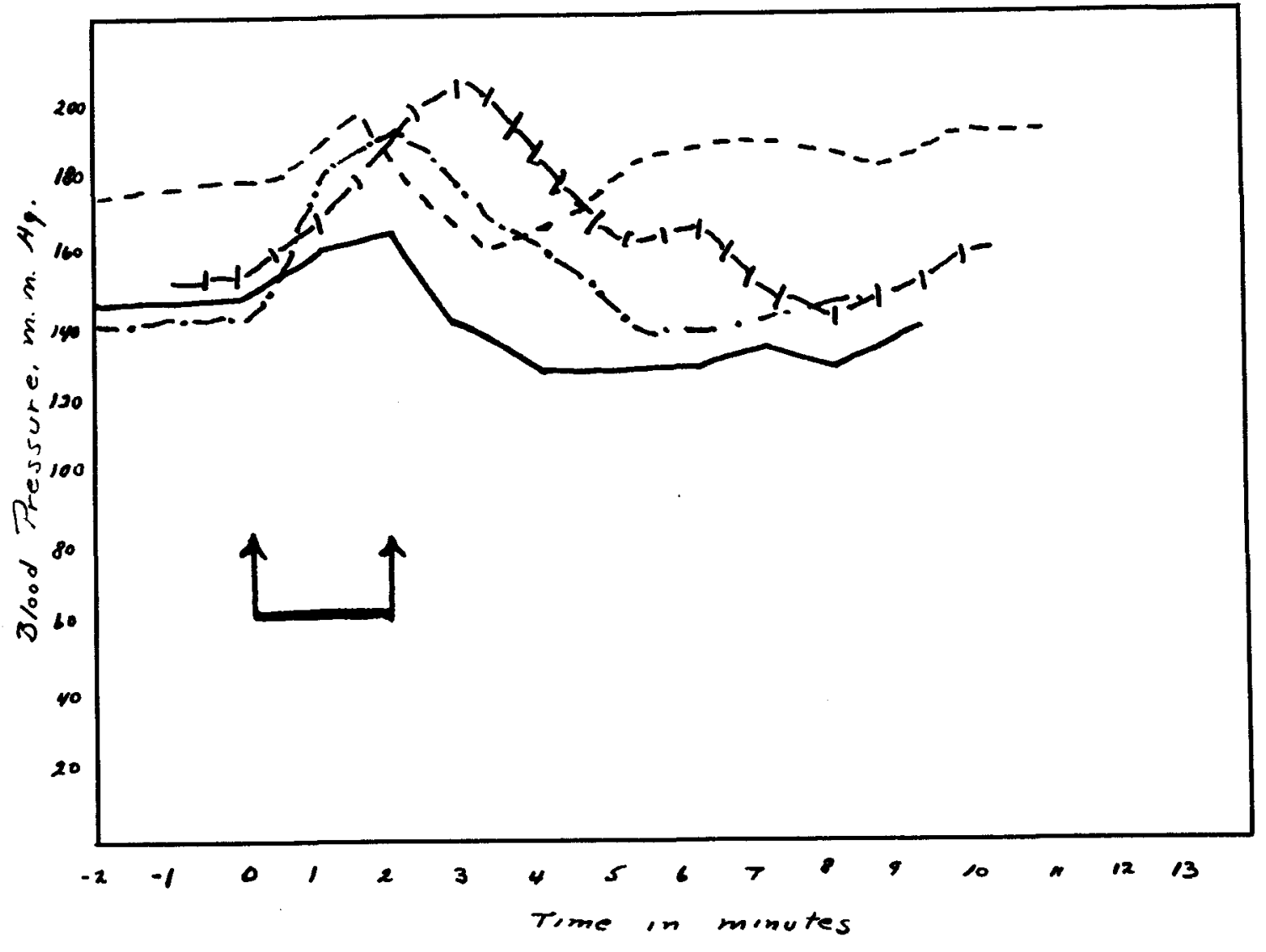

1 Amy' Nitmte 0.3 ce by Inhalation

$\operatorname{Dog} 1-2$

"2-6 - - - - -

" $3-1 \quad \cdots-\cdot-\cdots+\cdots$

" $y-1-1-1-1-1-1-1-1-1-$ 
Fig. 6. The Effect of Nitroglycerive on the Blood Pressure of Four Hypertensive Dogs.

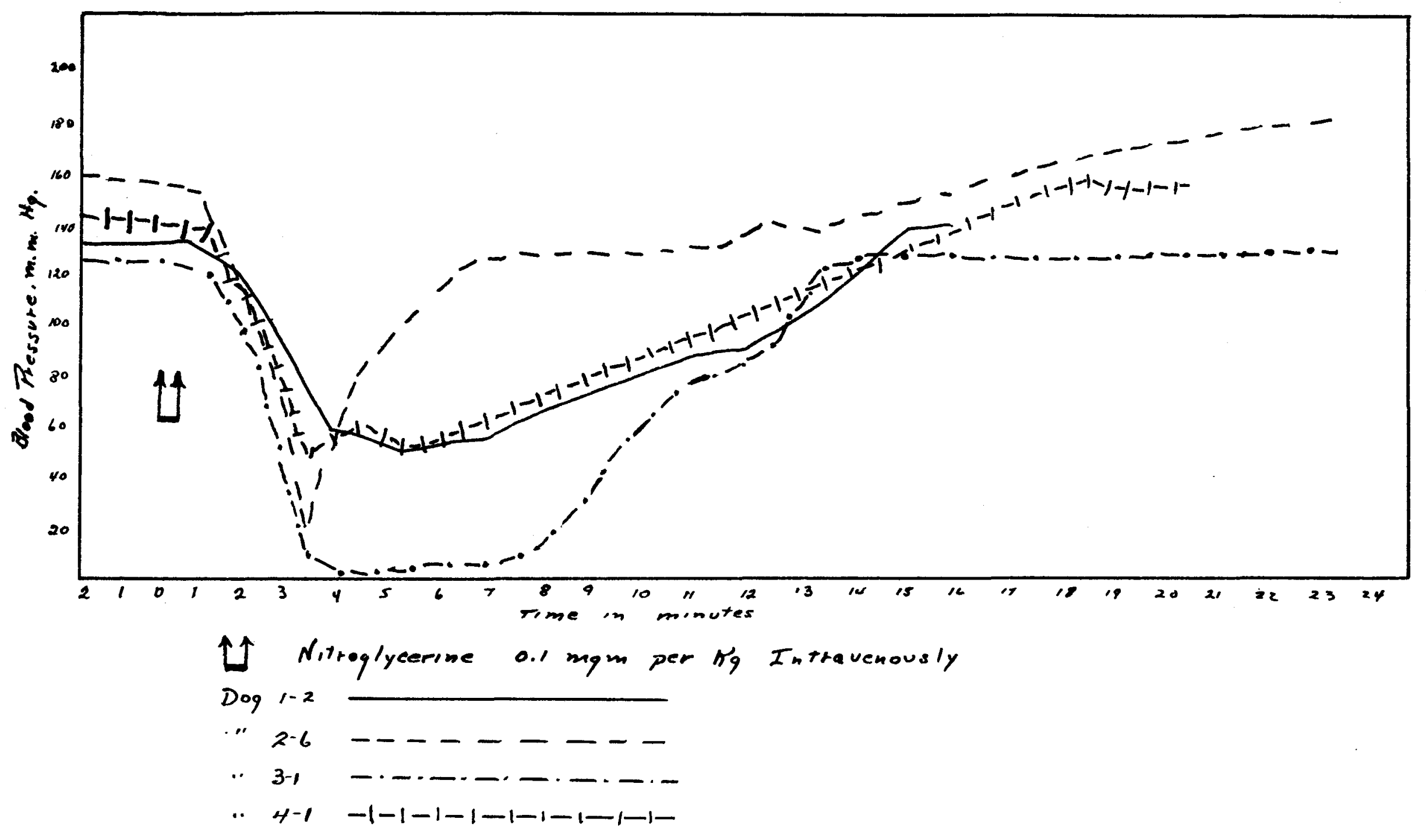


2-6 (FIg. 5) was s conewhat more 1rregular. After a transitory rise of $15 \mathrm{~mm}$. Hf., there was a sight temporery drop in blood pressure, which then returned to a level slightly higher then at first. Animal 3-1 (Fig. 5), showed a marked pressor action with anyl nitrite. The blood pressure rose from $150 \mathrm{~mm}$. Hg. to $190 \mathrm{~mm}$. Hg,, but the elevation lasted only fire minutes. In animal 4-1 (Fig. 5), there was a riee in blood pressure from 150 to 205 m. Hg. within two minutes and it did not come back to its original level for oight minutos.

2. Witroglyeerine. Then 0.1 mgm. per K8. of nitroglycerine was injected intraronously in $\operatorname{dog} 1-2$ (Fig. 6) the blood pressure dropped from 138 to $50 \mathrm{men}$. Ho. within four minutes or less, and then there was a progressire, slow rise wich oame back to a level slightly above the original level in ten minutes. The blood pressure $f_{a l l}$ in animal 2-6 (Fig. 6) was greater and more rapid. It went from 155 to $20 \mathrm{~mm}$. Hg. in three winutes, and then quickly returned to $120 \mathrm{~mm}$. Hg. In three nore minutes. Fran that point it gradually prooeeded up to its original level and surpassed it at the twontieth minute, after which it remained at definitely higher point. The recorded blood pressure of enimal 3-1 (Fig. 6) dropped to practically a zero level momentarily, and then fluctuated around the $10 \mathrm{~mm}$. nark for several minutes. During this time the animal manifested convalsions and urinary and fecal inoontinenoe, but he soon recovered when the blood pressure went up to higher 1evels. On the serenteenth minute the pre-injection point was reached. Dog 4-1 (Fig. 6) also showed a rapid fal 1 from 138 to $50 \mathrm{~mm}$. Hg., but the subsequent rise was more sxadual. The perlod of recovery extended over thirteen minutes and was followed, here again, by a slightly elovated plateau which perelated. dwring the succeeding four minutes of observatione 
Fig. 7. The Effect of Sodium Nitrite on the Blood Pressure of Four Hypertensive Dogs.

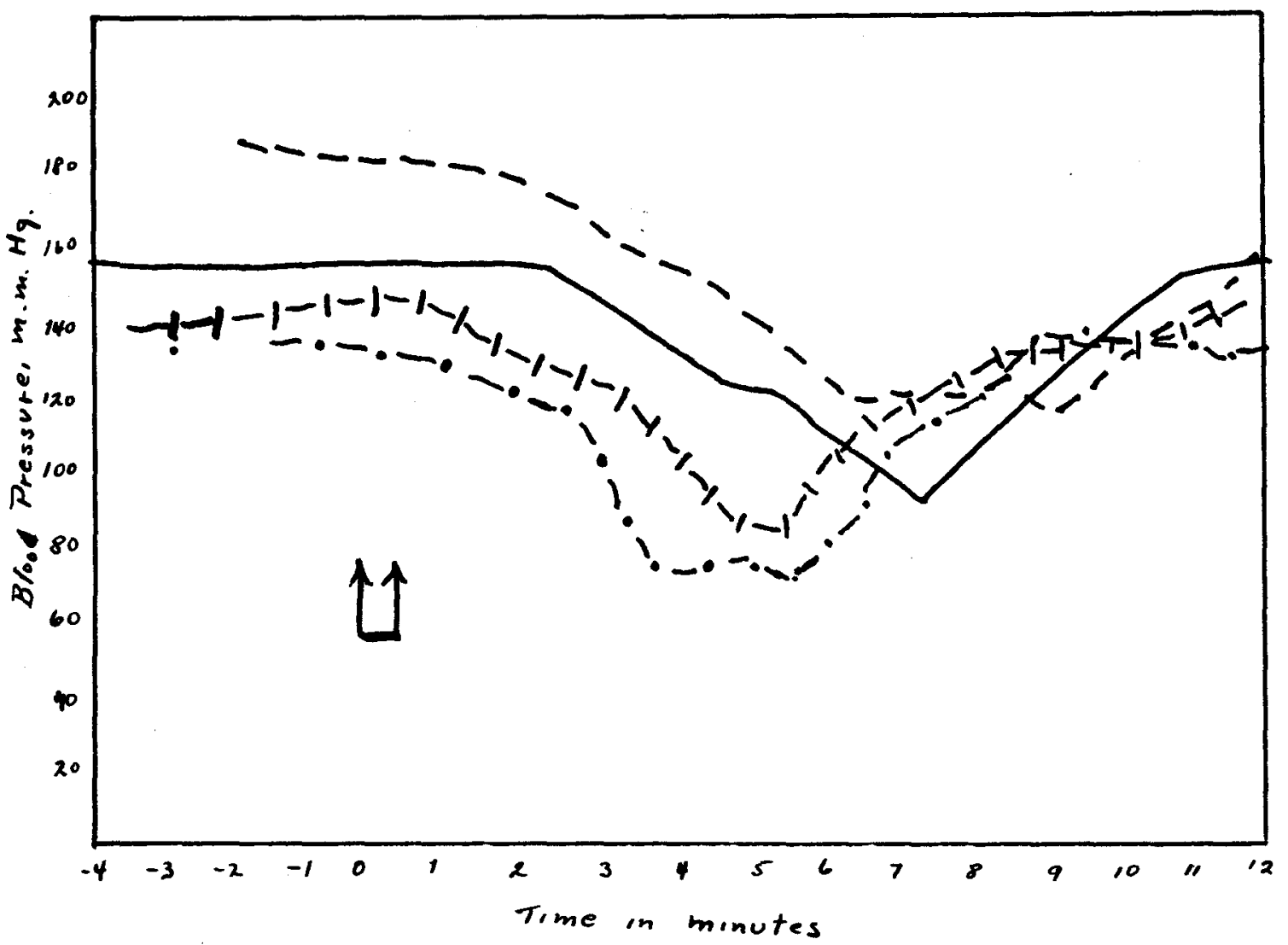

11 Sodium Nitrite songm per lig. Intravenously

$\operatorname{Dog} 1-2$

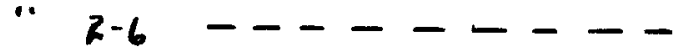

$\because 3-1 \quad \cdots-\cdot \cdots+\cdots$

" 4.1 -1-1-1-1-1-1-1-1-1- 
Fig 8. The Effect of Ether Anesthesia on the Blood Pressure of Mypertensive Dogs.

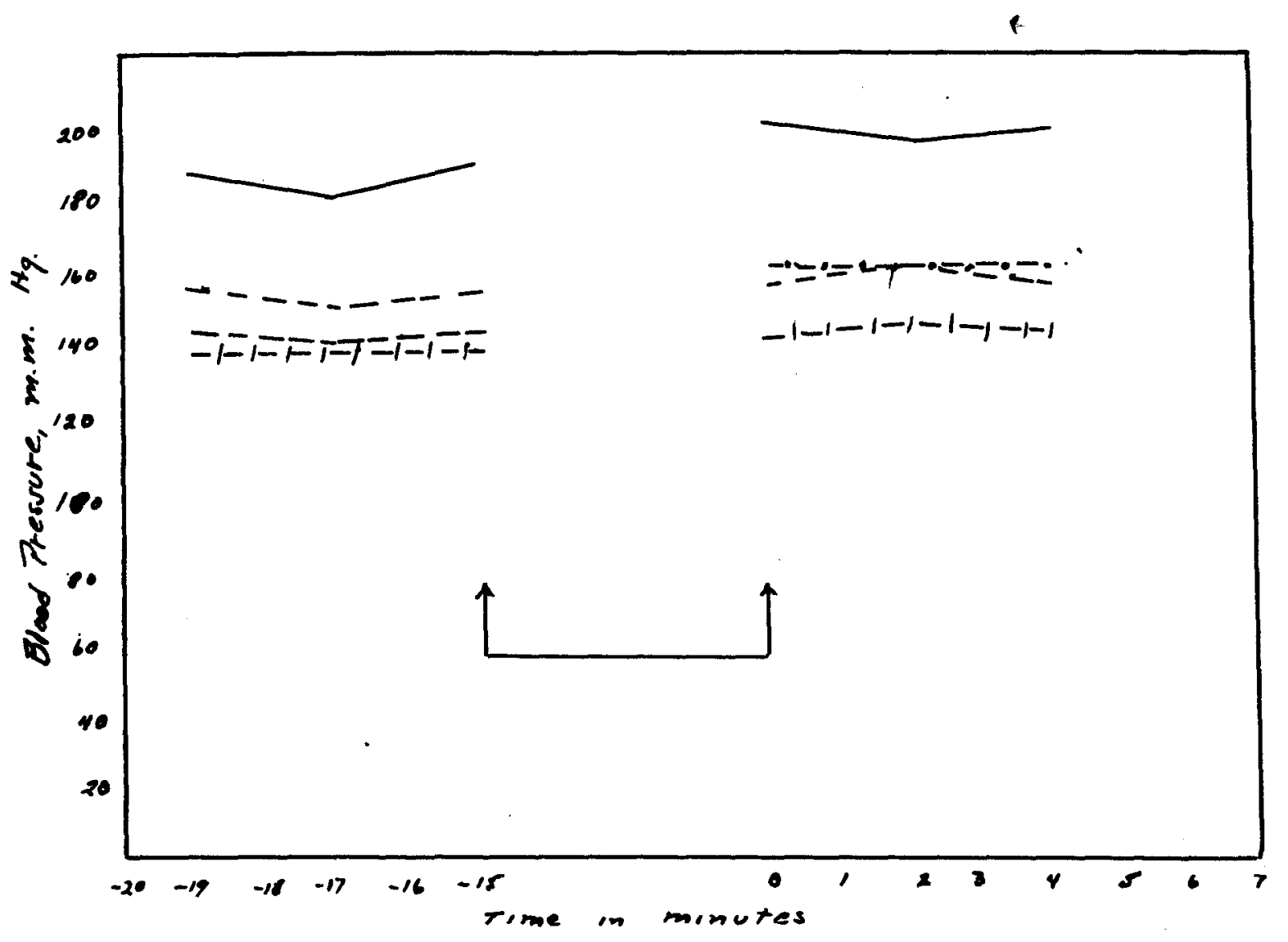

1 Induetion of Ether Anesthesia

$$
\begin{aligned}
& \operatorname{D\circ g} 1.2 \div------- \\
& \text { - } 2-6 \\
& \text { " } 3-1-\cdots-\cdots+\cdots \\
& \text {. 4-1 -1-1-1-1-1-1-1- }
\end{aligned}
$$


Fig. 9. The Effect of Sodium Pontobarbital on the Blood Pressure of Four Hypertensive Dogs.

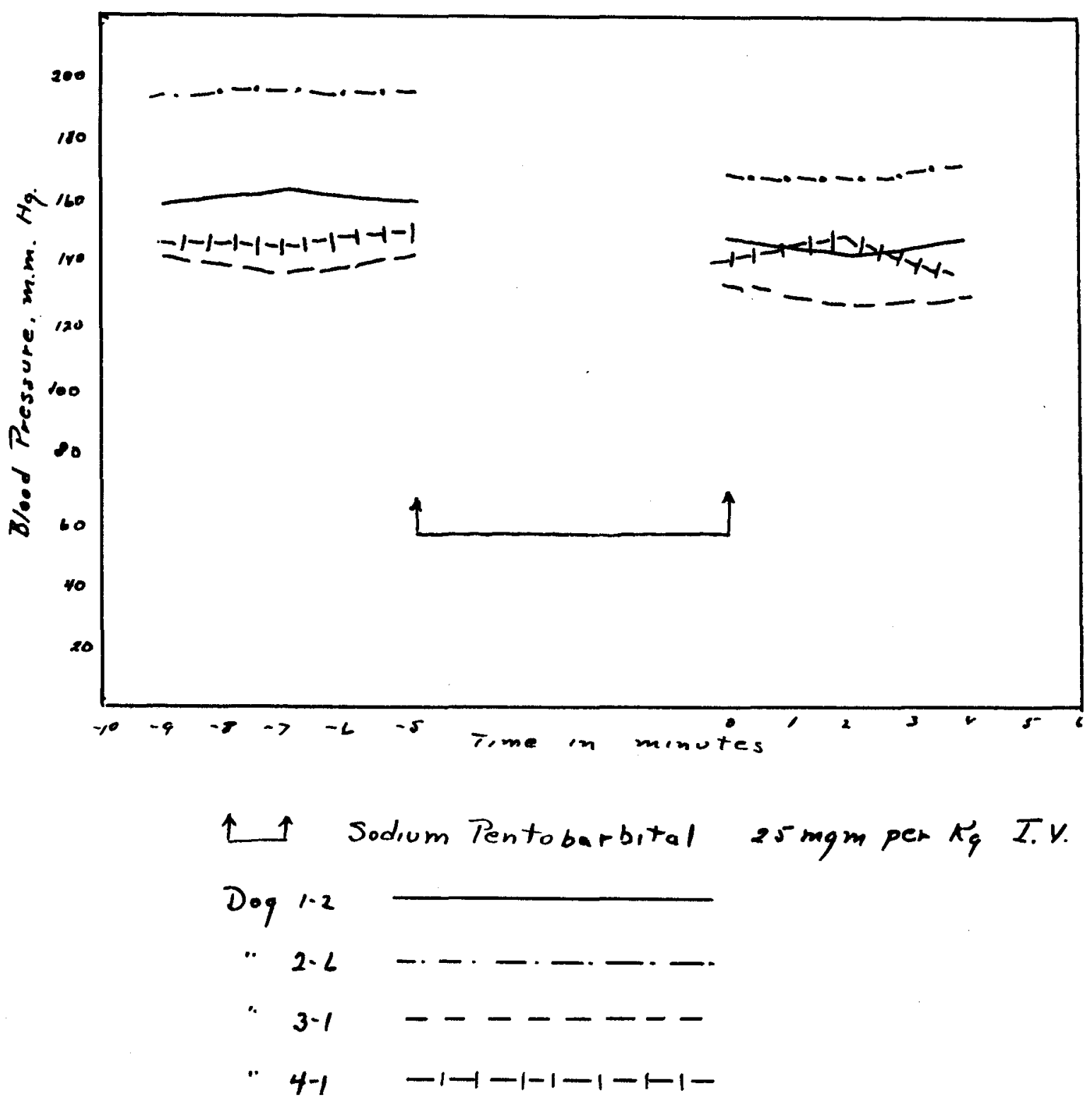


Fig. 10. The Effect of Mistamine Phosphate on the Blood Pressures of Four Hypertensive Dogs.

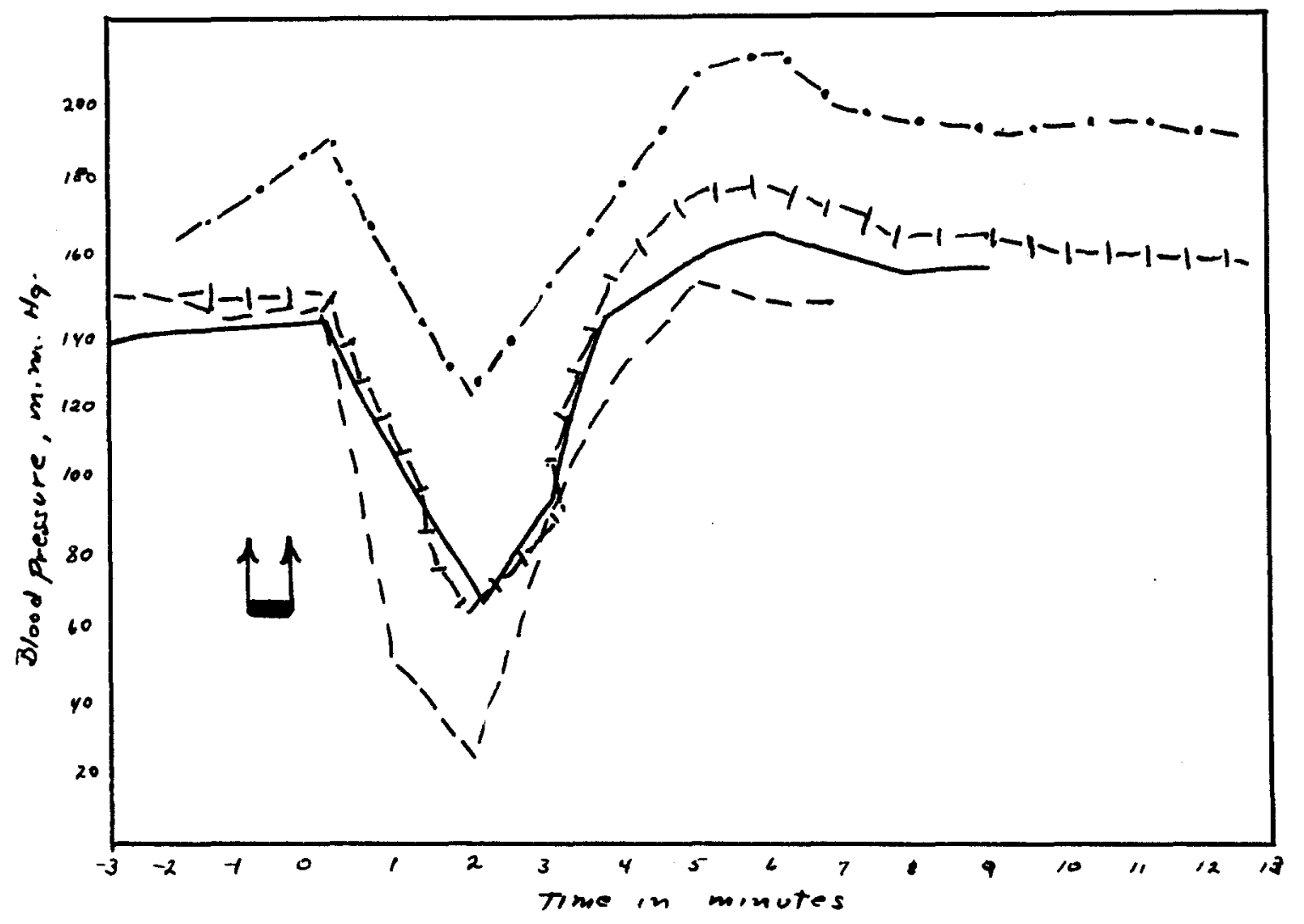

LI Histamine Phosphate $0.05 \mathrm{mgm}$ per H. I. I.

Dog $1-2$

$$
\begin{aligned}
& \text { " } 2.6-\cdots+\cdots \\
& \text { " } 3-1 \quad---1 \\
& \text { "y-1 }-1-1-1-1-1-1-1=
\end{aligned}
$$


3. Sodium Nitrite. Sodium nitrite, Emger por Intravenously during the period of obserration, in haimal 1-2 (Fig. 7) showed a gradual decline in blood pressure from 160 to $100 \mathrm{~mm}$. Hg. over a period of ix minutes, but soon it rose to its previous level in four minutes. Dog 2-6 (Fig. 7) showed a slow fall in blood preseure frcm 190 to $120 \mathrm{~mm}$. Hg., wher॰ It remained for three minutes, and then went up to $190 \mathrm{~mm}$. Hg. during the onsuing four minutes. In dog 3-1 (Fig. 7) the fall was from 135 to 80 m. Hg., the blood pressure remained at this latter mark for two minutes, and then rose to the pre-injection lovel. Animal 4-1 (Fig. 7) showed a gradual and moderate fall in blood pressure from 150 to $90 \mathrm{~mm}$. Hg. in four minutes with a subsequent rise to normal, similar to that shown by dog 3-1 (Fig. 7)。 4. Ether. Ether, by inhelation in an anesthetic dose, elevated the blood pressure of aninal 1-2 (Fig. 8) from 142 to $160 \mathrm{~mm}$. Hg. Dog 2-6 (Fig. 8) showed much the same thing. Its rise was from 190 to $200 \mathrm{~mm}$. Hg. In aninal 3-1 (Fig: 8) the rise was from 150 to $160 \mathrm{~mm}$. Hg. Dog 4-1 (Fig. 8) also showed a mall rise from 140 to $148 \mathrm{~mm}$. Hg.

5. Sodium Pontobarbital. Sodium pentobarbital, 25 mgm. per Ig., intrarenously in dog 1-2 (Fig. 9) produeed alight fall in blood pressure fram 162 to $150 \mathrm{~mm}$. Hg. In dog 2-6 (Fig. 9) the blood pressure was depressed frcm 190 to $170 \mathrm{~mm}$. Hg. $\operatorname{Dog} 3-1$ (Fig. 9) showed a slight fall from 145 to $130 \mathrm{~mm}$. Hg.., and in dog 4-1 (Fig. 9) it went from 150 tol40 m. Hg., but varied between those two levels subsequently.

6. Histamine Phosphate. Histanine phosphate, 0.05 mgn. Hg. Intravenously, produced a marked and rapid fall in blood pressure, (Fig. 10) wich began in about one or two minutes folloring injection, and lasted four or five minutes. This was followed by a moderate rise, which soon subsided, and the final blood pressure remained slightly above the original level during the period of observation. The greatest drop was $125 \mathrm{~mm}$. Hg. in one of the 
Fig. II. Effect of Acetycholine Bromide on the Blood Pressures of Four Hypertensive Dogs.

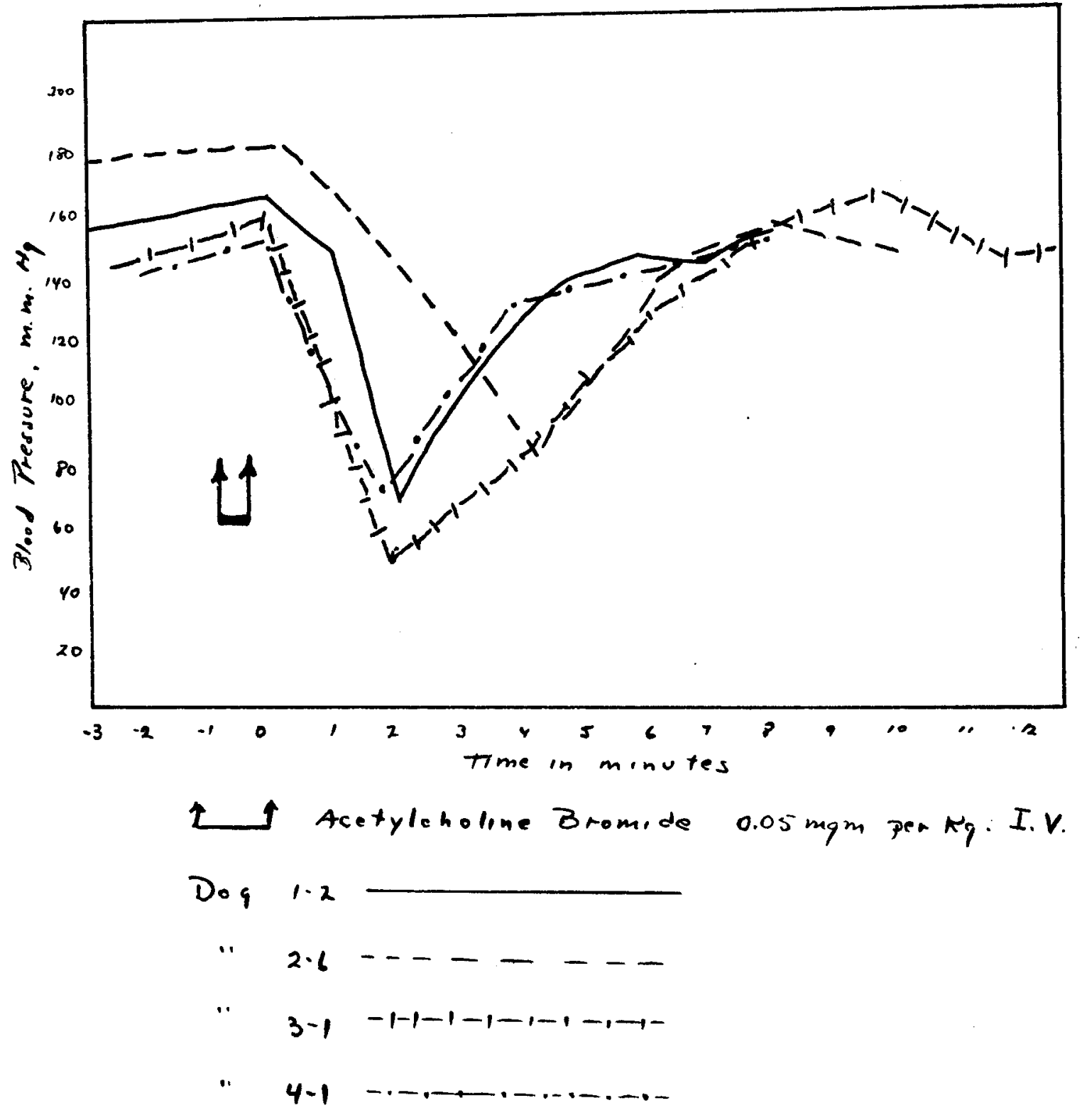


Fig. 12. The Effect of Pituitrin U.S.P. 10 Pressor Units on the Blood Pressupe of Four Hypertensive Dogs.

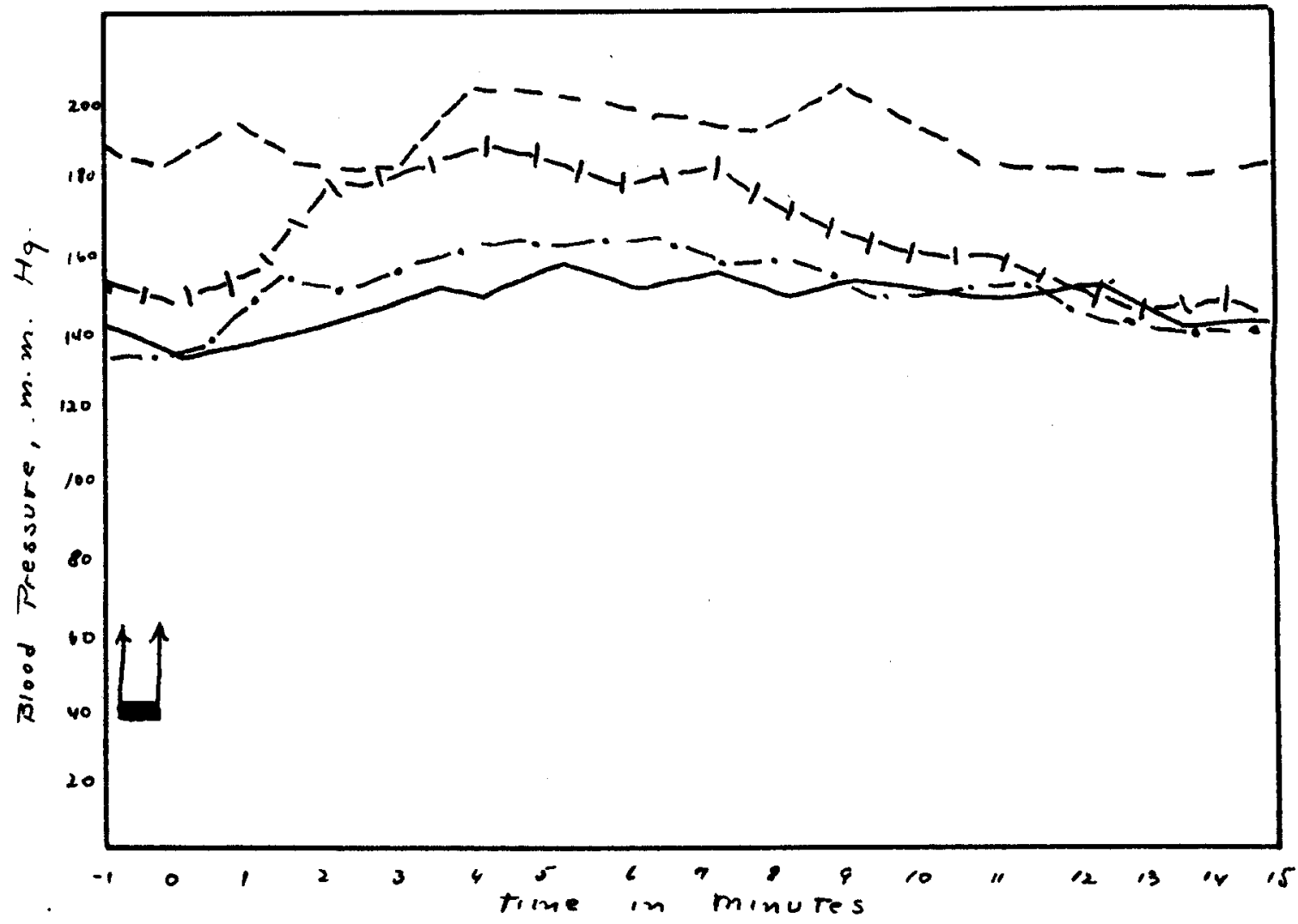

1 Pituitrin U.S.P. 10 Pressor Units intrayEnously Dog $1-2$
II
$2 \cdot 6 \quad-\cdots-\cdots-\cdots$
" $3-1$
. $4-1 \quad-1-1-1-1-1-1-1-1-1-1-$ 
Fig. 13. The Effect of Epinephrine Ardrochlonide on the Blood Pressures of Four Nypertensive Dogs.

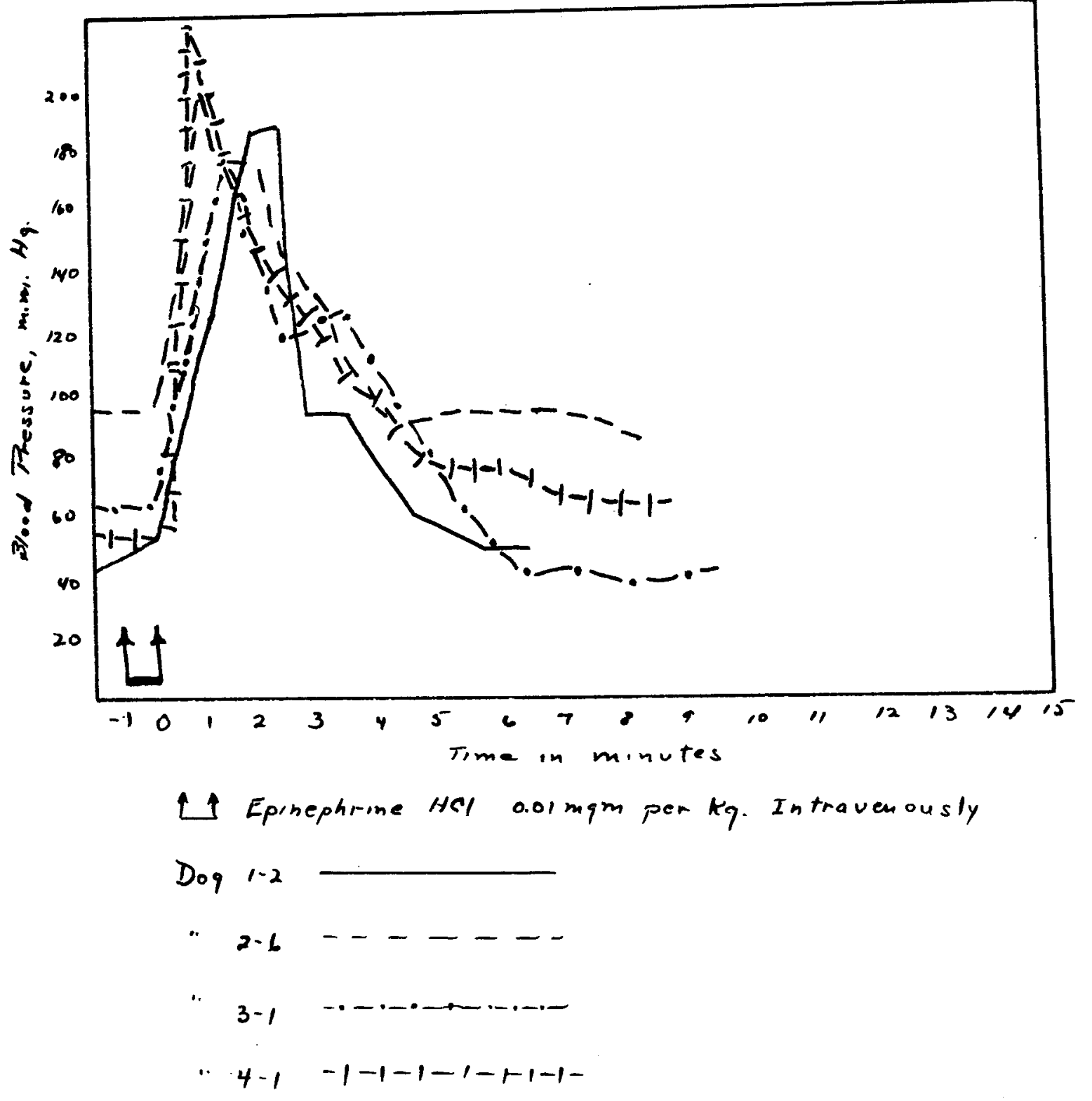


less hypextensive animals, 3-1, and the smallest depression of $40 \mathrm{~mm}$. Hg. was in the most hypertensire $d o g, 2-6.480$, in this antmal, the subsequent rise following the depression was higher and more prolonged.

7. Loetyleholine Bromide. Acetyleholine bromide, 0.05 mgm per $\mathrm{K}_{8}$, , when injeoted intravenously. produoed an immediate but transient lowering of blood pressur. (Fig. 11), with a momewhat more gradual rooovery than with histanino. There was a fleoting compensatory elevation in two dogs, and in the other two gogs there was a slight continued depression of the blood pressure during the period of observation, which was more pronounced in the nore hypertensive animel, (Dog 2-6).

8. Pituitrin (P.D. Co.) Then ten pressor units of U.S.P. pituitrin was injected intravonously (Fig. 12), it produced a rory moderate riso in blood pressure, which was sustained for a fairly long poriod of time. The rise ranted from 12 to $30 \mathrm{~mm}$. Hg., and was least in animal 2-6, (Fig. 12). The duration of the elevation of blood pressure varied from ten to serenteen minutes, and was shortest in 2-6, the most hypertensive animel. However, the highest and most prolonged rise did not ncour in the leadt hypertensire dog, but in one of the andmals with a moderate elevation of blood pressure, $(\operatorname{dog} 4-1$, Fig. 12).

9. Bpinephrine Hydroohloride. The effect of the intravenous injection of $0.01 \mathrm{mgm}$. per Fg. of epinephrine hydroohloride was to elevate the blood pressure almost imodiately to a rery high peak, where it remained only monentarily and soon fell back to its original letel. The height of the rise was from $280 \mathrm{~mm}$. Hg. in dog 3-1 (Fig. 13) to $300 \mathrm{~mm}$. Hg. in dog 2-6 (Fig 13). The duration of the eleration in blood pressure was from four minutes in dog 2-6 to seven minutes in dog 4-1 (Fig. 13). 


\section{DISCUSSION}

The Goldblatt method of produoing hypertension by renal isohemia in dogs has been found to be dependable, easily reproduced, and amenablo to many lines of inveatigation as to the possible pathogenesis of essential hypertonsion in humans. In the work presented here, the mothod has been modified 8lightly by first unilaterally nophreotomizing the experimental animal and thon clamping the other renal artery. In all the animals there was an immen diate and marked rise in blood pressure, which was nore pronounced in two of the $\operatorname{dog} 8$. No doubt if the olamp were tightened down more on the two remaining animals, the blood pressure there would also be at a higher lerel. These elevations of blood pressure have persisted for six woeks to three months in the animals, and are muoh above the blood pressures reachod at any time during the oontrol period.

The average mean blood pressure in alfthese animals was about $110 \mathrm{~mm}$. Hg., With extremes of from 84 to $130 \mathrm{~mm}$. Hg. during the control period. These figures are in olose agreenent with Parkins(122) values of 107.2 me. Hf. for the average blood pressure in 35 trained, unanesthetized normal dogs, wth extremes of from 92 to $120 \mathrm{~mm}$. Hg. He also used the Dameahek-Loman Instrument and obtained the blood pressure by direct intra-arterial punoture.

As has already boen stated, the etiology of essential hypertension is et111 unkenom(123) Howerer, the meth/ of produoing experimental hypertension by the Goldblatt technique, appears to have opened forew arenue of approach to this problen. Thue there aro cortain aspects of the experimental renal hypertention produced in dogs by renal ischemia, that are strikingly similar to the essential hypertension of humans. For exsmple, with moderate constriotion of the renal artery, the blood pressure beocmes olevated, but there ia no sign of reduoed ronal function. In this respeot the hypertension in these animals is similar to benign nephrosolerosis or essential hypertension in man. 
Alnost complete conetriotion of the artery in Goldblatt's experiment: resulted in great eleration of blood pressure which was acoompenied by serere disturbance of renal function and uremia. This resembles the typo of hypertension which is associated with malignant nophrosolerosis or malignant hypertension in humans. In view of these suggestive findings It ceens of interest to present further experimental ovidenoe for or against additional analogies between the Goldblatt type of hypertensi on and essontial hypertonsion as it exists in hymans. Honce this atudy was undertaken to determine the effeot of eertain drugs, the actions of which in the normal dog, and in normal and hypertensive humans are well lonown, on the Goldblatt type of experimental hypertension.

The rasodilatory properties of the nitrite group have been knom for a long time, and recently it hes even been olaimed that minute amounts of nitrites are normel constituents of the human blood (125). The nitrites act ohterly, if not entirely on the peripheral vasoular system and produce vasodilation, probably as a result of direot aotion on the cmooth musole of the ressel walls. The site of their activity is ohiefly the arterial side of the vasoular bed. In the four $\operatorname{dogs}$ used here, it was found that five minus of anyl nitrite by inhalation elevated the blood pressure, rather than lowered 1t. This was probably due to the fact that the drug was actministered in the usual way by inhalation, but the vapor proved irritating to the animal. and they responded by truggling. This oaused an eloration in blood prossure so marked that it owerome the transitory depressor effect of the anyl nitrite. Furthermore, the anount of amyl nitrite actually inhaled In some of the oaser, was so amall that it probably did not produce muoh of a vasodilator of feot in the first place. As is constantly observod in the normal animals " thudied in humons, both normal and hypertensive, nitro- 
glyoerine had a more profound but shorter depressor aotion in the bypertensive animals then did sodium nitrite.

Histamine phosphate ated as a potent rasodilator in all four of the animals, but the drop in blood pressure hero again was transient. These results, of course, are in agreement with the woll demonstrated de-

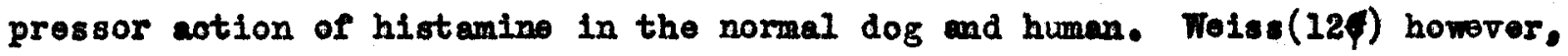
reported that in normal human subjecte, gtren en intravenous injection of histanine in doses of 0.001 pgm per Kg•, there was no appreoiablo lowering of the arterial blood pressure. Horeover, he found the same thing true In hypertensite humans. The difference between Foiss' results and our own in undoubtedly due to the faot that the dose which he employed was only $1 / 500$ th of the one used by us.

The work of Dale and his assooiates(126) has amply demonstrated that oholino, a derivative of looithin, and its osters, ropresent $\ldots \ldots$ potont rasodilator constituents of tissue extracts, and it is a remarkable faot that the introduotion of an aootyl radioal increases the physiologio potenoy of oholine in reduoing the arterial pressure by one hundred thousend tines. In the cireulation, however, the offect of aoetylcholine is only tranaient, owing to the faot that it is promptly destroyed in the blood strean. This was found to be the case in all the experimental animals that were subjeoted to the intravenous injection of acotyl-choline. Our results demonstrate that acetyloholine has depresscir effect in dogs with experimental hypertension similar to its depressor action in normal dogs. Howerer, Weise(12申), again finds that oren vhen asfiargo dose of 1 Gram of aootyloholine is infused Intravenously in the normal and hypertensive human over a period of ten minutes, the arterial pressure either remains normal, or 1s only slightly reduo ed. Here again, however, the dose employed by Woiss is approximately $1 / 25$ th of that used by us, which very likely acoounts for our positive, and his negative, finding6. 
Ether by inhalation in normal dogs is well known to oause a slight rise in the arterial blood pressuee(128). Collins and Hoffbauer(107) found that morphine-ether anesthesia does not lower the blood pressure of dogs with experimental ronal hypertension, but has a tendenoy to elorate it slightly. Our findings for ether are in agreenent with those of Collins and Hoffubaer, although morphine was not employed in our series of animals.

Sodium pentobarbital in anesthotio doses intravenously, oaused alight lowering of the blood pressure, which did not exoeed 20 to $26 \mathrm{~mm}$. H8. in the most hypertensive animal. In general, the barbiturates in anesthetis dosages in normal dogs produces no appreoiable lowering of the arterial blood pressure(12p). Naltor and P1foan(128), found that codium pentobarbital anesthosia caused but a elight fall in blood pressure from 200 to $190 \mathrm{~mm}$. Hg. syatolio, In a dog with hyportension due to ronal isohemia, (mothod of Bolablatt). This is about the degree of fall observed in the dogs investigated here. In no case did the blood pressure fall to normal levels.

The response to the pressor drugs, pituitrin, and opinephrine, is sinilar to that obtained in normal dogs and humans. The pressor response to pitultrin 18 slower and its action is more prolonged than with epinephrino. and the total height of the blood pressure rise with the former drug does not exoeed $40 \mathrm{~mm}$. Hg., in one of the moderately hypertensire animals. On the other hand, the most hypertensive dog had the least rise, which fras $20 \mathrm{~mm}$. H8. This difference probably resulted from the fact that tho arteriolar musoulature, already contracted down to a greater extent in the latter dog, did not respond as muoh to the direct stimulating action of pituitrin, as aid the 108 hypertenstre dogs. Bpinophrine produoed the sudden, rapid and transiont riso in blood pressure so oharaoteristio of its usual action in the normal dog. Reflex vagal slowing of the heat was also in eridenoe at the height of tho pressor reapense. To our knowiedge, no atudies have been made of the action 
of these drugs in tho humen with essential hypertension.

The results of these experiments, therefore, indieate that the nitrites, histamine, acotyloholine, other, codium pontobarbital, pituitrin and opinephrine, produce the seme qualitative ohenges in the arterial blood pressure in doge with experimental hypertenston due to renal isohemia, as In normal dogs, and in normal, and essential hypertensivo humans, to the extent that data for comparison are arailable. So far as the action of these drugs is conoerned, therefore, the hypertention present in Goldblatt dogs resembles that of the human with benign nephroselerosis. 


\section{SUMARY}

1. Porsistont hypertemsion was produo ed experinental iy in four dogs by neans of the Goldblatt teohnique of ronal ischemia, following unilateral nephreotony.

2. Transiont lowering of the blood pressure in these hypertensive dogs, was produced by the nitrites, histamine and aootylcholine.

3. Ether onesthesia elevated the blood pressure slightly.

4. Sodium pontobarbital slightly reduoed the blood pressure.

5. Pituitrin and opinephrine, produoed a more or less charaoteriatio temporary rise in blood pressure in these animals.

6. The drugs employed in this study, therefore, insofar as data for ocmparison are avallable, produoed blood pressure effeots in these four hypertensive dogs, which are analogaus to those observed in the normal dog, in the normal human, and in the human with easential hypertension.

7. These findings constitute additional ovidone of a similarity between the experimental hypertensi on due to renel isohomia in dogs and essential hypertension in man. 


\section{BIBLIOGRAPHY}

1. Fishberg: Hypertension and Iephritis, Lea and Ferbiger, Phila, 1931.

2. Janeways The Clinicel study of Blood Pressure. D. Appleton \& Co. Hew York, 1904.

3. Janeway: Nophritie Hypertension; Clinieal and Ixperimental Studies. Am. Journ. Ked. Sol.

4. Bright: Reports of Medical Ceses. London 1827.

5. Toynbee: Med. Chir. Trane., 1846, 29, 304.

6. Johnson: Ibid, $1858,51,57$.

7. Stophon Hales: Statieal Essays, containing Henostaticks. 1773.

8. Polseuillez Recherches sur la Force du Coour Aortique. Paris 1828.

8. Iudorig, Mullor's Archiv. f. Anatomie, Physiologie, etc. 1847.

10. Vierodt Archir. f. physiolische Hellkunde. 1856, 15, 225.

11. Von Basoh: 2tschr. f. Klin, Kod., 1884.

12.. Potain, Aroh, do, phys, norm. ot path,, 1890, 2, 300.

13. Riva-Roco1: Gazz. Hed, di Torino, 1896, 47, 981.

14. Olivar and Sohafert Journ. Physiol,, 1885, 18, 231.

15. Stewart: Journ. Exper. Mod., 1912, 16, 103.

16. Park, Ibid., 1812, 16, 523.

17. Hoskins and MeClures Am, Journ. Fhysiol,, 1812, 31, 587.

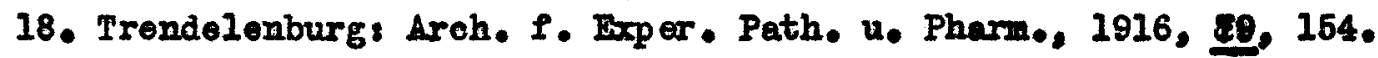

19. Sohur and Woinel: Woin. Klin. Wohnschr., 1907. 106, 95.

20. O'Connor: Arch, f. Exper. Path, u. Pharm, 1912, 67, 195.

21. Hulse: Zentralblatt $f$. Inn. Hed., 1922, 43, 1.

22. Kure, Hakaya, Muraksmi, Okinaka: Klin. Ksohr., 1933, 12, 454.

23. Ieimdorfer: Woin. Klin, woch., 1926, 39, 41.

24. Yenendess Rer. Soc. Argent. Biol., 1932, 8, 463.

25. Yenender and Braun: Compte Rendus de Sog. B101,, 1932, 111, 477.

26 Cushing: An. Journ. Path., 1934, 10, 145. 
27. Kylin, Deutoh. Aroh. Klin. Mod., 1034, 276, 301.

28. Blount: Journ. Expt. Z001,, Wistar B1bliogr. Serv•, August, 15, 1935.

29. Tigerstedt and Bergmann: Skan. Arch. f. Phys., 1898, 8, 223.

80. Hartwichs Ztsohr. f. d. ges. exp. Med., 1930, 69, 462.

31. Cashs Johns Hopkin: Hosp. Bull, 1924, 55, 168.

32. Pearcer Joum. Exp. Hed., 1909, 11. 430.

33. J. L. and E. M. Yiller: Journ. Physiol., 1911, 43, 242.

34. Volhard, Vorhand, Doutoh, Gosell, f. Inn, Mod,. 1923, 35, 134.

35. Huelse and Stranss: Ztsch, f. d. ges. exp. Med., 1924, 39, 426.

36. Fuelse and Frankes Aroh, f. exp. Path, u. Pharm, 1929, 143, 257.

37. Bohn: Verhand1. Deutch. Kong. f. Inn. Mod., 1930, 42, 198.

88. Petrovsky PIluger' Arohives, 1925, 210, 294.

89. Danser, Brody and Miles, Proc. Soc. Exp. Biol, and Med., 1926, 23, 454.

40. Agatston, Am. Journ. Opth,, 1933, 16, 327.

41. Weiser: Zentralblatt f. Inn. Med., 1934, 55, 65.

42. Hantehmon, Z. ges. Exp. Yod., 1936, 96, 442.

43. Curtis, Monoriof and Wright, Joum. Path, and Bact., 1927, 30, 65.

44. Capps and Ferris, Proc. Soo. Bxp. Biol, and Med., 1834, 31, 1106.

45. Ioiter: Aroh. Int. Mod., 1936, 57, 4.

46. Pages Journ, Bxp. Med., 1935, 61, 67.

47. Piokering, Clin, Soi, incl, Heart, 1936, 2, 191.

48. Yajor: Johns Hopkins Hosp. Bull, 1925, 36, 357.

Am. Journ. Yod. So1., 1925, 170, 228.

49. Greemwald, Journ. Biol, Chem,. 1924, 69, 329.

60. Thites Journ. Biol. Chem., 1927, 71, 419.

51. Pages Proo. Soo. Brp. Biol, and Med., 1936, 36,, 112.

52. Jostphol, Ztsohr. F. KIIn. Med., 1925, 101, 545.

53. Burger: Klin. Wohnschr., 1930, 9, 525. 
54. Fahr: Verhand d. Deutoh. Path, Gesell., 1912, 15, 234.

55. Van Leersum: Zeitsohr. f. Exper. Path. u. Therap., 1912, 2, 408.

56. Solmidtmami Virohow's Arch. f. Path, Anat., 1922, 237, I.

57. Sohonheiner: Virohow's Aroh. I. Path. Anat, 1824, 249, 1.

68. Shopiro and $S_{\theta i c o f}$ Journ. Lab, and Clin. Yed, 1925, 10, 826.

59. Horing: Verhand. Doutch, Gesell, f. Inn, Mod., 1923, 35, 93.

60. Kooh and Mies: Krantheitsforsohung, 1929, I, 241.

61. Hoymans and Bouokaerts Compte Rondus Soc. de Biol., 1931, 106, 471.

62. Kremer, Fright and Soarf, Brit, Journ. Bxp. Path., 1933, 14, 281.

63. Groen, De Groat and MeDonald: Am. J. Phys101,. 1935, 110, 513.

64. De Jaegher and Van Bougaert, Compte Rendus Soc. de Biol., 1935, 118, 544.

65. Hoff and Urbans Klin. Wsohr., 1938, 12, 1366.

66. Beokmen: Vorhandl, phyikelish-mediz. Gezell. Wuergberg. Proceedings for oct. 31, 1857, rol. 8, 1858.

67. Koellioker, Disouseion of preoeeding.

68. Strauss: Aroh, gen. de Med., 1882, I (7th series), 1.

69. Rautenberg: Deutch. Med. Wohnsohr., 1910, 36, 61.

70. Paussier and Hoineke: Verhandl. Deutoh, path. Gesel 1., 1905, 9, 99.

71. Balnbridge and Beddard, Proc. Roy. So0., 1907, 75, 798.

72. Pearces Journ, Bxpt. Med., 1908, 10, 632 .

73. Janeway: Proc. Soc. Bxp. Biol. and Mod., 1909, 6, 109.

74. Piloher: Journ. Biol. Chem. 1913, 14, 389.

75. Andersons Journ. Bxper. Med., 1924, 34, 707.

Aroh. Int. Med., 1926, 34, 313 .

76. Allen, Scharf, Lundin, Journ, Exper. Yed., 1925, 35, 608.

77. Yarks Gin. WBohr., 1925, 4, 281.

78. Mark and Gelsendorfer, Klin. WBch., 1930, 9, 182.

79. Forris and Hynes: Journ. Lab, and Clin. Yod., 1931, 16, 697.

80. Apfelbach and Jensen, Doutoh, Aroh. f. Klin. Med, 1931, 151, 1. 
81. Freidman and Wachamuch, Aroh. f. exp. Path. u. Pharm, 1930, 150, 173. 82. Chanutin and Forris: Arch. Int. Mod., 1932, 47, 767.

83. Food and Ethridges Proo. Soc. Exp. Biol. and Med., 1933, 30, 1039. 84. Ploks Woise. IIn. Woch., 1935, June 6. 85. Rafiky, Bernhardt, Rhodenberg, An. Journ. Med. So1., 1935, 190, 187. 86. Major and Weber: Aroh. Int. Med., 1937, 10,891. 87. Thamas, Aroh, do mal du ooour., 1926, 17, 641. 88. Tholldtes Zlegler's Beitrage, 1927, 77, 61. 89. Yosler: 2twchr. f. KIIn. Mod., 1912, 74, 297. 90. Bacheant 2tschr. f. d. ges. exp. Med., 1916, 4., 63. 91. Hartman, Balliger and Doub, Am. Journ. Yod. So1., 1926, 172, 487. Journ. An. Mod. As8n., 1927, 89, 1936.

92. Page: An. Journ. Med, So1., 1936, 191, 251.

93. Bell and Pedersen: Ann. Int. Med., 1930, 4, 227.

94. Henendez: Rev. Soo. Arg. Biol., 1932, 8, 651.

95. Goldblatt, Lymch, Hanzel and Summervilles Journ. Expt. Med., 1934, 59, 510. 96. Van Leersum: Pfluger's Arch., 1911, 142, 377.

97. Pages Am. Journ. Phys101, 1935, 112, 166.

98. Page and Heuer, Journ. Clin. Invest., 1935, yㅗ, 443.

99. Elaut: Compte Rondus Soc. B101., 1936, 122, 126.

100. Goldblatt, Gros8, Hanzal, Journ. Expt. Med., 1937, 65, 233.

101. Page: Am. Journ. Physio,, 1935, 112, 166.

102. Harrison, Blalooh, Mason: Proo. Soo. Hxpt. Med. Bio., 1936, 35, 38. 103. Prinemetal and Friedman: Ibid., 122.

104. Dicker: Compte Rondus Soc. Biol., 1936, 122, 476. 
105. Page: Proo. Soo. Expt. Biol. and Med., 1936, 35, 112.

106. Prinimetal, Friodman and Rosenthal: Proc. Soc. Expt. Bio. and Mod., 1936, 34, 545

107. Collins and Hoffbauer: Proc. Soc. Expt. Blol. and Med., 1936, 35, 539.

109. Jemenay: Proc. Soo. Exp. Bl01. and Med., 1919, 6, 108.

110. Kollst Journ. Pharm. and Exp. Ther ap., 1820, 15, 443.

111. Forris and Hyness See Ref. 79.

112. Gaertner: Yunch. Yed. Woch., 1900, 1195.

113. Trendelenberg: Zøitschr. Ixp. Med., 1913, 2, 1.

114. Frank: Tigeratedt's Handbuch der Physiologischen nethodik, 1913, II, 1.

115. Tiggers: Pressure pulses in cardio-vascular system, 1938.

Longmans, Green \& Co.

116. Hemilton, Brower and Brotman: Am. Journ. Physiol., 1934, 107, 427.

117. Pavlov: Pflugers Aroh., 1878, 16, 266.

118. Brooks: Heart, 1910, $\underline{2}, 5$.

119. Trendelenberg and Fleischaure, W. Ztschr. f. d. ges. Exper. Med., 1908, 6, 108.

120. Damesher and Loman: Am. Journ. Physiol., 1932, 101, 140.

122. Parkins: Am. Journ. Physiol., 1934, 107, 518.

123. Weis8: Am. Int. Med., 1934, 8, 296.

124. Woises Mod. CIin. H. A., March 1936.

125. Steiglitz and Palmer: Journ. Pharm. and Expt. Therap., 1934, 51, 398.

126. Dale \& Lanoet, 1929, 1, 1238.

Arch. Int. Med., 1923, 49, 360 .

127. Sollman: I Manual of Pharmacology 4th Ed., 1934. W. B. Saunders \& Co., Phila.

128. Nalter and Pijoan: Surgery, 1937, $1,282$. 